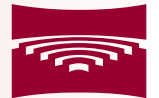

Rīgas STRADIN,a UNIVERSITĀTE

\title{
Lauma Springǵe
}

\section{VARDARBĪBAS IZRAISĪTIE VESELİBAS TRAUCËJUMI BĒRNIEM UN JAUNIEŠIEM LATVIJĀ}

Promocijas darba kopsavilkums medicinas doktora zinātniskā grāda iegūšanai Specialitāte - sabiedrības veselība un epidemioloǵija 


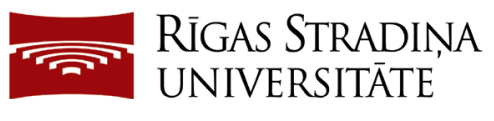

Lauma Sprinğge

\section{VARDARBĪBAS IZRAISĪTIE VESELİBAS TRAUCĒJUMI BĒRNIEM UN JAUNIEŠIEM LATVIJĀ}

Promocijas darba kopsavilkums
medicīnas doktora zinātniskā grāda iegūšanai

Specialitāte - sabiedrības veselība un epidemioloǵija 
Promocijas darbs izstrādāts Rīgas Stradiņa universitātē.

Darba zinātniskā vadītāja:

Dr. med. asociētā profesore Anita Villeruša, Rīgas Stradina universitāte, Latvija

Oficiālie recenzenti:

Dr. med. profesors Ģirts Briǵis,

Rīgas Stradina universitāte, Latvija

Dr. psych. profesore Sandra Sebre,

Latvijas Universitāte

Dr. med. profesore Birute Strukcinskiene,

Klaipēdas Universitāte, Lietuva

Promocijas darba aizstāvēšana notiks 2017. gada 26. septembrī plkst. 15.00 Rīgas Stradinna universitātes Medicīnas promocijas padomes atklātā sēdē Rīgā, Dzirciema ielā 16, Hipokrāta auditorijā.

Ar promocijas darbu var iepazīties RSU bibliotēkā un RSU tīmekḷa vietnē: www.rsu.lv.

Promocijas padomes sekretāre:

Dr. med., Mg. sc. sal. docente Inese Gobina 


\section{ANOTĀCIJA}

Ievads. ANO Ilgtspējīgas attīstības 16.1. mērḳis paredz, ka sabiedrībā ir būtiski jāsamazina visu veidu vardarbība. Bērni ir sabiedrības daḷa, kas ir īpaši aizsargājama no vardarbības un tās izraisītajām nelabvēlīgajām sekām. Lai apzinātu un sekmīgi risinātu vardarbības problēmu, ir nepieciešams apzināt problēmas apmērus, kā arī izprast tās ietekmi uz bērnu veselību un labklājību ilgākā laika periodā. Vardarbība ir multifaktoriāls fenomens, tādēḷ tās izpētē, rezultātu interpretācijā un problēmas risināšanā ir jāṇem vērā ǵimenes, vietējās kopienas, kultūras un sabiedrības vērtību, uzskatu un attieksmes ietekme.

Darba mērkis bija izpētīt vardarbības un to veidu izplatību Latvijas bērnu un jauniešu populācijā, aplūkot vardarbības saistību un to sakarības ar gimeni raksturojošiem faktoriem, veselību un tās traucējumiem, kā arī noskaidrot no vardarbības cietušo bērnu rehabilitācijas iespējas.

Materiāls un metodes. Darba kvantitatīvā pētījuma dạ̦ā izmantoti dati, kas iegūti reprezentatīvā šķērsgriezuma pētījumā par Latvijas jauniešu bērnības nelabvēlīgo pieredzi. Balstoties uz PVO rekomendācijām, kā pētījuma instruments izmantota bērnībā gūtās nelabvēlīgās pieredzes (The Adverse Childhood Experiences (ACE) Study) aptaujas anketa. Kopumā analizēti 1223 gadījumi. Statistiskajā datu apstrādē lietots biežumu sadalījums, šķērstabulas un $\mathrm{H}_{\overline{1}}$ kvadrāta $(\chi 2)$ tests. Saistību noteikšanai izmantotas nesamērotās izredžu attiecības, stratificētā izredžu attiecība pēc Mantela-Hansela metodes, Spīrmena korelācijas koeficients un daudzfaktoru logistiskā regresija.

Darba kvalitatīvā pētījuma daḷā, lai iegūtu informāciju par ekspertu pieredzi darbā ar vardarbībā cietušajiem bērniem, veiktas padziḷinātas, daḷēji strukturētas ekspertu intervijas ar psihologiem, psihoterapeitiem un ārstiem psihoterapeitiem, kuri strādā ar bērniem, kuri cietuši no vardarbības. Kopumā intervēti 14 eksperti. Interviju datu apstrādē izmantota tematiskās analīzes metode. 
Rezultāti. Visbiežāk jaunieši bērnībā ir pieredzējuši emocionālo vardarbību $(31,5 \%)$, fizisko $(27,0 \%)$ un emocionālo $(23,8 \%)$ nevērību, bet retāk - fizisko $(16,4 \%)$ un seksuālo $(10,3 \%)$ vardarbību. Sievietes vardarbību pieredzējušas biežāk nekā vīrieši. Lielākas izredzes pieredzēt vienu vai vairākus vardarbības veidus bija tiem bērniem, kuru gimenēs ir šādi riska faktori: zems sociāli ekonomiskais stāvoklis, vecāku šķiršanās, tēva vardarbība pret māti, psihoemocionālās veselības un alkohola lietošanas problēmas, salīdzinājumā ar bērniem no gímenēm, kurās nav iepriekš minēto riska faktoru. Daudzfaktoru regresijas analīze liecina, ka tiem jauniešiem, kuri bērnībā pieredzējuši kādu no vardarbības veidiem (izṇemot seksuālo vardarbību), ir 1,2-2,2 reizes (atkarībā no modelī iekḷautā vardarbības veida) lielākas slikta veselības pašvērtējuma izredzes nekā jauniešiem bez vardarbības pieredzes. Bērnībā pieredzēta fiziskā un emocionālā vardarbība 1,4 un 1,2 reizes palielināja pārmērīga alkohola lietošanas izredzes jauniešu vecumā. Tiem jauniešiem, kuri bērnībā pieredzējuši fizisko, emocionālo vardarbību un emocionālo nevērību, jauniešu vecumā ir attiecīgi 2,6, 2,3 un 2,1 reizes lielākas psihiskās veselības problēmu attīstības izredzes nekā jauniešiem bez šādas pieredzes. Bērnībā pieredzēta vardarbība (izṇemot seksuālo vardarbību) 2,2-4,0 reizes palielināja pašnāvības mēǵinājumu veikšanas izredzes jauniešu vecumā salīdzinājumā ar jauniešiem, kuriem nav vardarbības pieredzes.

Pēc interviju kodēšanas jautājumu sadaḷā par cietušo vardarbības pieredzi un vardarbības jēdziena izpratni iezīmējās trīs tēmas - vardarbības jēdziena konceptualizācijas dažādība, bērnu vardarbības pieredzes raksturojums un bērnu atklātība par pieredzēto vardarbību. Sadaļā par vardarbības ietekmi uz cietušo bērnu veselību izkristalizējās divas tēmas - sekas uz fizisko un psihoemocionālo veselību un veselību ietekmējošie faktori. Jautājumu sadạā par to, kādā veidā no vardarbības cietušie bērni pārvar vardarbības izraisītos traucējumus un kāda loma šajā procesā ir institūcijām, izkristalizējās trīs tēmas: traucējumu 
pārvarēšanas stratēgiju raksturojums, darbs ar bērnu, kurš cietis no vardarbības cietušo bērnu, rehabilitācijas sistēmiskās vajadzības.

Secinājumi. Vardarbība pret bērniem ir aktuāla Latvijas sabiedrības veselības problēma. Lielākas izredzes pieredzēt vardarbību ir bērniem no disfunkcionālām g̛imenēm. Bērnībā pieredzētā vardarbība saistīta gan ar sliktāka veselības pašvērtējuma izredzēm, gan ar pārmērīgas alkohola lietošanas, psihoemocionālās veselības problēmu attīstības un pašnāvības mēǵinājumu veikšanas izredzēm jauniešu vecumā. Svarīgākās tēmas ekspertu interviju analīzē: vardarbības jēdziena konceptualizācija, vardarbības pieredzes raksturojums, vardarbības izraisītās sekas un to pārvarēšanas mehānismi, kā arī no vardarbības cietušo bērnu vajadzības rehabilitācijas procesā. 


\section{SATURA RĀDĪTĀJS}

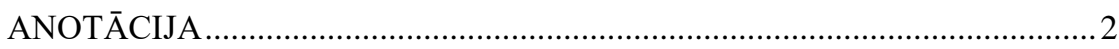

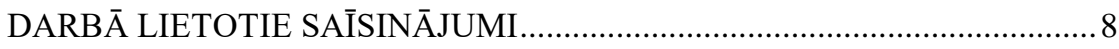

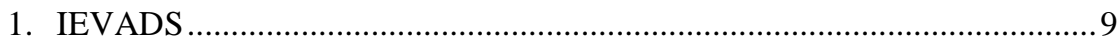

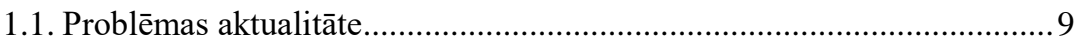

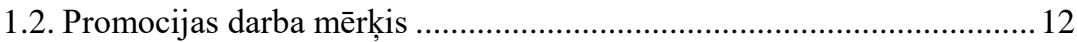

1.3. Promocijas darba uzdevumi................................................................... 12

1.4. Promocijas darba hipotēzes ..................................................................... 13

1.5. Promocijas darba pētniecības jautājums ...................................................... 13

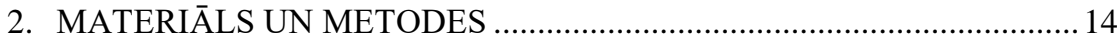

2.1. Kvantitatīvās pētniecības daḷa ...................................................................14

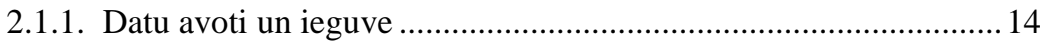

2.1.2. Pētāmo mainīgo pazīmes un grupēšana ........................................ 14

2.1.3. Pētāmās populācijas raksturojums ............................................... 17

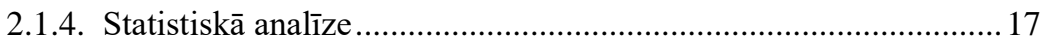

2.2. Kvalitatīvās pētniecības daḷa ..................................................................19

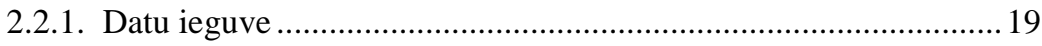

2.2.2. Atlase un respondentu raksturojums .............................................. 20

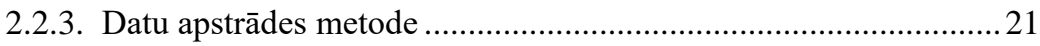

3. KVANTITATĪVĀ PĒTĪJUMA REZULTĀTI ............................................23

3.1. Vardarbības izplatība un vardarbības veidu savstarpējās sakarības.......23

3.2. Bērnībā pieredzētās vardarbības saistība ar ğimeni raksturojošiem faktoriem...................................................................... 24

3.3. Jauniešu veselību un ğimeni raksturojošie faktori ...................................2 27

3.4. Bērnībā pieredzētā vardarbība un jauniešu veselību

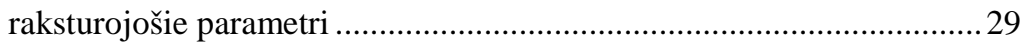

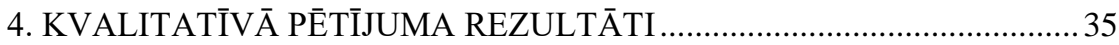


4.1. Cietušo bērnu vardarbības pieredze un vardarbības jēdziena izpratne .. 35

4.1.1. Vardarbības jēdziena konceptualizācijas dažādība ......................... 35

4.1.2. Bērnu vardarbības pieredzes raksturojums...................................... 35

4.1.3. Cietušā bērna atklātība par notikušo vardarbību .............................. 36

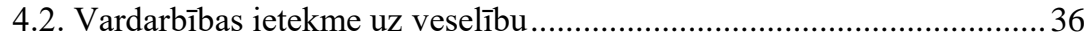

4.2.1. Ietekme uz fizisko un psihoemocionālo veselību............................ 36

4.2.2. Veselību ietekmējošie faktori.......................................................... 37

4.3. Vardarbības izraisīto traucējumu pārvarēšanas stratēǵijas,

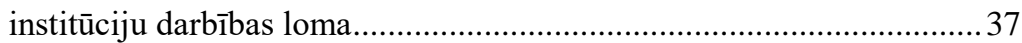

4.3.1. Traucējumu pārvarēšanas stratēǵiju raksturojums .......................... 37

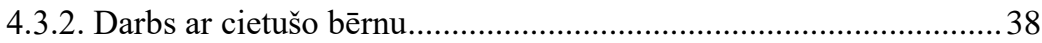

4.3.3. Rehabilitācijas sistēmiskās vajadzības ............................................ 39

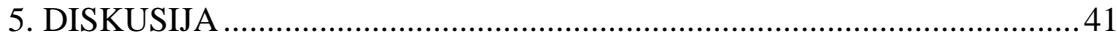

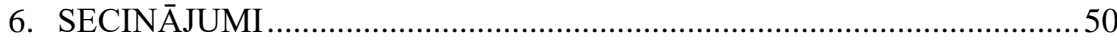

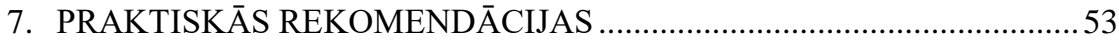

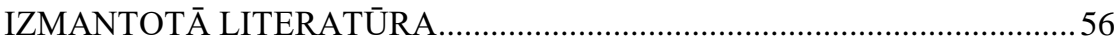

PUBLIKĀCIJAS UN TĒZES PAR DARBA TĒMU ......................................5 59

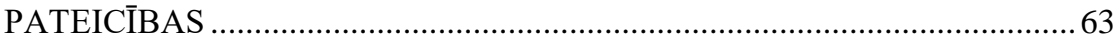




\section{DARBĀ LIETOTIE SAĪSINĀJUMI}

ANO Apvienoto Nāciju Organizācija

PVA Pasaules Veselības asambleja

PVO Pasaules Veselības organizācija

MK Ministru kabinets

SES sociāli ekonomiskais stāvoklis 


\section{IEVADS}

\subsection{Problēmas aktualitāte}

Vardarbība ir sabiedrībā aktuāla problēma, kas ne tikai ierobežo indivīda tiesības uz drošu un no vardarbības brīvu dzīves telpu, bet arī atstāj paliekošas nelabvēlīgas sekas uz indivīda un visas sabiedrības veselību. ANO Ilgtspējīgas attīstības 16.1. mērḳis paredz, ka sabiedrībā ir būtiski jāsamazina visu veidu vardarbība (United Nations, 2017). Pamatojoties uz šo mērḳi, 2016. gada 27. maijā 69. Pasaules Veselības asamblejā pieņemta rezolūcija (PVA 69.5) par PVO Globālo rīcības plānu starppersonu vardarbības mazināšanai, īpaši uzsverot sievietes un bērnus kā neaizsargātākās sabiedrības grupas (World Health Organization [WHO], 2014a).

Bērni ir viena no sabiedrības grupām, kurām ir nepieciešama īpaša aizsardzība pret vardarbību. Saskaņā ar statistikas datiem Eiropas reǵionā ik gadu vardarbīgā nāvē mirst aptuveni 850 bērnu vecumā līdz 15 gadiem (WHO, 2013a), tomēr vēl lielāks ir to bērnu skaits, kuri ikdienā saskaras ar vienu vai pat vairākām vardarbības formām - fizisko, emocionālo, seksuālo vardarbību un nevērību jeb atstāšanu novārtā. Ģimenei ir jābūt vietai, kurā bērns var saņemt nepieciešamo aprūpi un atbalstu, lai varētu attīstîties un sekmīgi sagatavoties patstāvīgai dzīvei, tomēr gimene var būt arī bērna veselību un labklājību apdraudoša vieta, jo vardarbība pret bērniem visbiežāk notiek tieši ǵimenē (Gilbert et al., 2009).

Pret bērniem vērstās vardarbības izplatības rādītāju apzināšana ir viens no PVO izvirzītajiem uzdevumiem. PVO Eiropas ziņojumā par vardarbības pret bērniem mazināšanu, balstoties uz vairāku pētījumu datiem, aprēḳināti bērnībā pieredzētās vardarbības prevalences rādītāji. Visbiežāk bērni cietuši no emocionālās $(29,1 \%)$ un fiziskās $(22,9 \%)$ vardarbības, savukārt no emocionālās nevērības cietuši 18,4\% bērnu, bet no fiziskās nevērības - 16,3\%. Visretāk 
sastopama seksuālā vardarbība pret bērnu - 13,4\% meiteņu un 5,7\% zēnu (WHO, 2013). Ziņojumā uzsvērts, ka nepieciešami jauni pētījumi, lai labāk apzinātu pret bērniem vērstās vardarbības izraisīto slogu, īpaši uzmanību pievēršot tieši emocionālajai vardarbībai un nevērībai.

Pret bērniem vērstās vardarbības izplatības rādītāju interpretācijā ir vairāki specifiski aspekti, kas var ietekmēt rādītāju vērtību. Pirmkārt, būtiska nozīme ir izmantotajam datu avotam. Pret bērniem vērstās vardarbības gadījumi, kas registrēti institūcijās, ir tikai dą̣a no visiem vardarbības gadījumiem. Pilnīgākai problēmas izpētei un apzināšanai izmanto epidemiologiskos populāciju pētījumus, aptaujājot respondentus par vinuu gūto vardarbības pieredzi. Ir aprēķināts, ka institūcijās apzinātais pret bērniem vērstās vardarbības gadījumu skaits atšķiras līdz pat desmit reizēm salīdzinājmā ar gadījumu skaitu, kas apzināts populāciju aptaujās (Gilbert, 2009). Otra nozīmīga problēma saistīta ar vardarbības jēdziena uztveri un izpratni sabiedrībā. Vardarbība pret bērniem kā specifiska sabiedrības problēma aktualizēta tikai pagājušajā gadsimtā, tomēr atsevišḳi vardarbības veidi, piemēram, emocionālā vardarbība pret bērnu kā atsevišķa vardarbības forma pētīta un aprakstīta tikai pēdējo 25 gadu laikā (Cindy and Miller-Perrin, 2013). Līdz ar to izpratne par vardarbību pret bērniem un tās dažādajām formām sabiedrībā nav viennozīmīga, turklāt vardarbības jēdziena izpratni ietekmē arī vietējās kopienas, kultūras un sabiedrības vērtības, uzskati un attieksme (Pinheiro, 2006). N̦emot vērā problēmas aktualitāti un augstos izplatības rādītājus, kā arī vardarbības fenomena interpretācijas dažādību, būtiski ir noskaidrot vardarbības pret bērniem izplatību arī Latvijas populācijā.

Bērnībā pieredzētai vardarbībai ir ne tikai tūlītējas negatīvās sekas, bet tā var atstāt arī nelabvēlīgas ilgtermiņa sekas uz cietušās personas veselību un labklājību. Epidemioloǵijas un neirobioloǵijas pētījumos gūtie pierādījumi liecina, ka bērnībā pieredzētas vardarbības izraisītais stress rada izmaiņas cietušās personas smadzeņu struktūrā un fiziolog̣ijā. Tas var ietekmēt cilvēka uzvedību, kā arī ilgtermiṇā atstāt nelabvēlīgas sekas uz veselību (Anda et al., 
2006). Pētījumos novēro atšķirīgus veselības un ar veselības uzvedību saistītos rādītājus atkarībā no tā, vai respondents bērnībā ir pieredzējis pret sevi vērstu vardarbību.

Valsts politikas dokumentos jaunieši kā nākotnes cilvēkkapitāls ir viena no prioritātēm. Latvijas Jaunatnes politikas īstenošanas plānā 2016.2020. gadam (2016, Nr. 256) jauniešu veselība ir norādīta kā viens no būtiskiem priekšnosacījumiem sekmīgai indivīda pārejai no bērna uz pieaugušo vecumu un pilnvērtīgai jaunieša integrācijai sabiedrībā. Kā liecina aptaujas dati, Latvijas 16-24 gadus veco jauniešu veselības pašvērtējums ir augstāks nekā kopējais Latvijas iedzīvotāju veselības pašvērtējums, taču ES dalībvalstu vidū Latvijas jauniešiem ir zemākais laba vai ḷoti laba veselības pašvērtējuma īpatsvars (LR Centrālā statistikas pārvalde [CSP], 2014). Veselība ir viens no dzīves kvalitātes komponentiem un būtisks priekšnosacījums produktivitātei un sociālajai labklājīibai, tādēḷ ir būtiski noskaidrot un apzināt jauniešu veselību potenciāli ietekmējošos faktorus.

Psihisko veselību raksturojošie parametri atspoguḷo jauniešu spēju tikt galā ar sava vecumposma izaicinājumiem un problēmām. Iedzīvotāju veselības paradumu pētījumu dati liecina, ka 39,3\% jauniešu vecumā no 15 līdz 24 gadiem pēdējā mēneša laikā ir izjutuši sasprindzinājumu, stresu un nomāktību (Slimību profilakses un kontroles centrs [SPKC], 2015). Tāpat Latvijas jauniešu populācijā novēro arī augstus pašnāvības rādītājus - pašnāvība ir otrs biežākais nāves cēlonis 15-25 gadu vecuma grupā (WHO, 2017).

Pētījumos par bērnībā pieredzēto vardarbību ir novērota saistība starp bērnībā pieredzētu vardarbību un pārmērīgu alkohola lietošanu vēlākā dzīves periodā. Latvijas jauniešu populācijā pārmērīga alkohola lietošana ir viena no būtiskām sabiedrības veselības problēmām. Starptautiskā pētījuma ESPAD rezultāti liecina, ka pēdējā mēneša laikā alkoholu lietojuši 63\% zēnu un 67\% meiteņu 15 gadu vecumā. Latvijā šis rādītājs ir augstāks nekā kopējā pētījuma populācijā, kurā iekḷautas 35 Eiropas reǵiona valstis (SPKC, 2016). 
Pamatojoties uz jauniešu veselības un ar veselību saistîtās uzvedības aktualitātēm Latvijas jauniešu populācijāa kā arī citviet pasaulē veiktajiem pētījumiem par bērnībā pieredzētās vardarbības nelabvēlīgo ietekmi uz indivīda vēlāko dzīvi, promocijas darbā analizēta bērnībā pieredzētās vardarbības ietekme uz Latvijas jauniešu veselības pašvērtējumu, pārmērīgu alkohola lietošanu, psihoemocionālās veselības problēmām un pašnāvības mēǵinājumiem.

\subsection{Promocijas darba mērḳis}

Darba mērkisis ir izpētīt vardarbības un tās veidu izplatību Latvijas bērnu un jauniešu populācijā un to sakarības ar ǵimeni raksturojošiem faktoriem, veselību un to raksturojošiem parametriem, kā arī noskaidrot ekspertu viedokḷus par vardarbībā cietušo bērnu izpratni par notikušo vardarbību, vardarbības izraisītajām sekām, to pārvarēšanas mehānismiem un rehabilitāciju.

\subsection{Promocijas darba uzdevumi}

1. Noskaidrot bērnībā gūtās fiziskās, emocionālās, seksuālās vardarbības pieredzes dzimumspecifisko prevalenci jauniešu populācijā.

2. Analizēt bērnībā pieredzēto vardarbības veidu saistību ar ǵimeni raksturojošiem sociālajiem, ekonomiskajiem un psihoemocionālajiem faktoriem.

3. Noskaidrot bērnībā pieredzēto vardarbības veidu saistību ar jauniešu veselību raksturojošiem parametriem.

4. Izvērtēt bērnībā pieredzēto vardarbības veidu neatkarīgo ietekmi uz veselību raksturojošiem parametriem, samērojot tos ar jaunieša demogrāfiskajiem un gimeni raksturojošajiem faktoriem. 
5. Noskaidrot psihologu un psihoterapeitu, kuri strādā ar vardarbībā cietušiem bērniem, pieredzi un skatījumu uz cietušo bērnu izpratni par notikušo vardarbību, par vardarbības izraisītajām sekām, to pārvarēšanas mehānismiem un rehabilitāciju.

\subsection{Promocijas darba hipotēzes}

1. Pastāv sakarības starp gimeni raksturojošiem faktoriem un bērnībā pieredzētās vardarbības un nevērības veidiem jauniešu dzimumu grupās.

2. Pastāv atškirīibas jauniešu veselību raksturojošajos parametros starp jauniešu grupām ar dažādu bērnībā gūto vardarbības pieredzi.

\subsection{Promocijas darba pētniecības jautājums}

Kādi ir ekspertu viedokḷi par vardarbībā cietušo bērnu vardarbības pieredzi, tās ietekmi uz veselību un vardarbības izraisīto traucējumu rehabilitāciju? 


\section{MATERIĀLS UN METODES}

\subsection{Kvantitatīvās pētniecības daḷa}

\subsubsection{Datu avoti un ieguve}

Promocijas darbā izmantoti dati, kas iegūti no Slimību un profilakses kontroles centra 2011.gada pētījuma par Latvijas jauniešu bērnībā gūto nelabvēlīgo pieredzi. Pêtījuma dizains ir retrospektīvs šķērsgriezuma pētījums. Pētījuma mērķa populācija ir Latvijas jaunieši. Pētījuma instruments ir jau izstrādāta un starptautiski atzīta aptaujas anketa par bērnībā gūto nelabvēlīgo pieredzi.

\subsubsection{Pētāmo mainīgo pazīmes un grupēšana}

\section{Atkarīgās pazīmes}

Veselības pašvērtējums. Atbildes tika dihotomizētas, izveidojot divas grupas - labs (apvienojot atbilžu variantus "labs” un “diezgan labs”) un slikts (apvienojot atbilžu variantus "vidējs", "slikts", "ḷti slikts") veselības pašvērtējums.

Alkohola lietošana par pārmērīgu tika uzskatīta, ja respondents atbildējis, ka pēdējo 30 dienu laikā ir bijis piedzēries vismaz vienu reizi.

Psihoemocionālās veselības problēmas noteiktas, ja pēdējo sešu mēnešu laikā respondents vismaz reizi nedēḷā izjutis vismaz divas no četrām sūdzībām (nomāktība, aizkaitināmība, nervozitāte un grūtības iemigt).

Pašnāvības mēǵinājumi noskaidroti lūdzot respondentus atbildēt uz jautājumu "Vai Tu esi kādreiz mēǵinājis/-usi izdarīt pašnāvību?". 


\section{Neatkarīgās pazīmes}

Fiziskās vardarbības pieredze noskaidrota, uzdodot jautājumus: "Cik bieži, Tev augot, kāds no Taviem vecākiem, pamāte/patēvs vai cits Tavā mājāa dzīvojošs pieaugušais: (1) purināja, grūstīja, iepḷaukāja vai meta ar cietu priekšmetu; (2) sita tik stipri, ka Tev palika sitiena pēdas vai tiki savainots?”. Fiziskā vardarbība tika definēta, ja pirmajā jautājumā respondents atzīmēja atbilžu variantus "bieži”, "ḷoti bieži” un/vai otrajā jautājumā atzīmēja "vienu, divas reizes", "reizēm", "bieži”, "ḷoti bieži”.

Emocionālās vardarbības pieredze noskaidrota izmantojot divus jautājumus: "Cik bieži, Tev augot, kāds no Taviem vecākiem, pamāte/patēvs vai cits Tavā mājā dzīvojošs pieaugušais: (1) lamāja Tevi, aizvainoja vai pazemoja un (2) rīkojās tā, ka Tu baidījies Tev varētu tikt nodarītas fiziskas sāpes?”. Emocionālās vardarbības pieredze tika definēta, ja pirmajā jautājumā respondenti atzīmēja "bieži” vai "ḷoti bieži” un/vai otrajā jautājumā atzīmēja “vienu, divas reizes”, "reizēm”, “bieži”, "ḷoti bieži”.

Lai novērtētu seksuālās vardarbības pieredzi, respondentiem uzdoti divi jautājumi: "Vai līdz 18 gadu vecumam kāds pieaugušais, vecāks radinieks, ǵimenes draugs vai svešinieks kādreiz ir veicis zemāk minētās darbības? (1) aizticis vai glāstījis Tavu ḳermeni seksuālā veidā, (2) mēǵinājis panākt jebkāda veida dzimumaktu (orālu, anālu vai vaginālu) ar Tevi”. Seksuālā vardarbība definēta, ja uz vienu vai abiem jautājumiem respondents atbildējis apstiprinoši.

Fiziskā nevērība pret bērnu mērīta, izmantojot piecus apgalvojumus: "Cik bieži katrs no šiem apgalvojumiem ir patiess, domājot par laiku līdz 18 gadiem? 1) Tev pietrūka ēdamā. 2) Tavi vecāki/audžuvecāki bija pārāk piedzērušies vai apdulluši no narkotikām, lai rūpētos par ǵimeni. 3) Tev nācās valkāt netīru apg̣ērbu. 4) Tu zināji, ka ir kāds, kurš par Tevi rūpējas un pasargā. 5) Nepieciešamības gadījumā bija kāds, kurš aizveda Tevi pie ārsta.” Fiziskā nevērība definēta gadījumos, ja respondents uz kādu no pirmajiem trim 
jautājumiem atbildēja ar "bieži”, "ḷoti bieži”, bet pēdējos divos jautājumos “nekad”, "reti”.

Emocionālās nevērības noskaidrošanai izmantoti šādi jautājumi:

“Cik bieži katrs no šiem apgalvojumiem ir patiess, domājot par laiku līdz 18 gadiem? 1) Tavā ğimenē bija kāds, kurš Tev palīdzēja justies svarīgam/-ai vai īpašam/-ai. 2) Tu ǵimenē juties mīlēts/-a. 3) Cilvēki Tavā ǵimenē cits par citu rūpējās. 4) Tu juti, ka gimenē kāds Tevi ienīst. 5) Tu domāji, ka Tavi vecāki vēlas, kaut Tu nekad nebūtu piedzimis/-usi.” Emocionāla nevērība definēta, ja kādā no pirmajiem trim jautājumiem norādīti atbilžu varianti "nekad", "reti”, bet ceturtajā un piektajā jautājumā atzīmēts "reizēm”, "bieži”, “ ’,oti bieži”".

Promocijas darbā iekḷautas vairākas neatkarīgās pazīmes, kas raksturo respondenta ğimenes vidi. Ģimenes sociāli ekonomiskā stāvokḷa noskaidrošanai izmantota Ģimenes pārticības skala (angl. - Family Affluence Scale).

Lai iegūtu informāciju par vecāku šḳiršanos vai dzīvošanu atsevišḳi, respondentiem vaicāts, vai vecāki jebkad ir dzīvojuši šķirti vai bijuši šķ̄irušies.

Lai novērtētu tēva vardarbību pret māti, respondentiem uzdoti četri jautājumi ar atbilžu variantiem "nekad", "vienu, divas reizes", "reizēm”, "bieži”, "loti bieži”: "Kamēr Tu augi, cik bieži Tavs tēvs/patēvs vai mātes partneris: (1) grūstīja, purināja, meta viņai ar priekšmetu; (2) spēra, rāva aiz matiem vai sita viņai ar dūri vai kādu cietu priekšmetu; (3) ilgstoši sita, spārdīja vairākas reizes; (4) draudēja viņai ar nazi vai šaujamieroci ar mērḳi viņu savainot?”. Pret sievieti vērstas vardarbības ğimenē gadījumi noteikti, ja respondents uz pirmo jautājumu atbildējis ar "bieži", "ḷoti bieži” vai otrajā jautājumā - "reizēm", "bieži", "ḷoti bieži”, vai arī trešajā un ceturtajā jautājumā atzīmējis atbilžu variantus "vienu, divas reizes", "reizēm”, "bieži”, “ḷoti bieži”.

Pārmērīga alkohola lietošana ǵimenē definēta, ja respondents atbildējis apstiprinoši uz jautājumu, vai viņa gimenē ir bijis kāds, kuram ir bijušas ar alkohola lietošanu saistītas problēmas vai kurš bijis alkoholiķis/-e. 
Psihiskās veselības problēmas ğimenē definētas, ja respondents atbildējis apstiprinoši vismaz uz vienu no šiem jautājumiem: 1) Vai ǵimenē kāds ir bijis ilgstoši nomākts vai psihiski slims? 2) Vai ǵimenē kāds ir mēǵinājis izdarīt pašnāvību?

\subsubsection{Pētāmās populācijas raksturojums}

Kopumā datu analīzē iekḷauti 1223 (615 vīrieši un 608 sievietes) respondenti vecumā no 18 līdz 25 gadiem. Vidējais respondentu vecums bija 18,6 gadi (standartnovirze 0,98 ). No visiem respondentiem $89,9 \%$ bija vecumā no 18 līdz 20 gadiem. No visiem respondentiem 59,3\% $(\mathrm{n}=725)$ mācījās vidusskolā, bet 40,7\% $(\mathrm{n}=498)$ - profesionālās izglìtības iestādē. Vispārizglītojošās skolās tikai 10 no respondentiem bija vecāki par 19 gadiem, savukārt profesionālās izglītības iestādēs respondentu vecumu sadalījums bija šāds: 18 gadi (37,1\%), 19 gadi (35,5\%), 20 gadi $(14,9 \%), 21$ gads $(5,8 \%), 22$ gadi (3,1\%), 23 gadi (1,9\%), 24 gadi $(1,0 \%)$ un 25 gadi $(0,8 \%)$.

\subsubsection{Statistiskā analīze}

Datu analīzei izmantotas aprakstošās statistikas metodes: biežumu sadalījums, vidējo vērtību aprēḳināšana, šḳērstabulas. 2 × 2 tabulās respondentu apakšgrupu salīdzināšanai izmantots Hī kvadrāta (angl. - chi-square) tests. Lai salīdzinātu neatkarīgās grupas, kuru skaits ir vairāk par divām, izmantota procentuālo atšķirību statistiskās ticamības intervāla noteikšana, izmantojot Vilsona intervāla aprēḳina (angl. - Wilson Score Interval) metodi (Erdoğan and Gülhan, 2016). Spīrmena korelācijas (angl. - Spearman correlation) koeficients izmantots, lai noteiktu korelācijas starp vardarbības veidiem. 
Lai noteiktu asociāciju starp atkarīgo un neatkarīgo pētāmo pazìmi, izmantots izredžu attiecību aprēķins (angl. - odds ratio). Asociācijai starp bērnībā pieredzēto vardarbību un ǵimeni raksturojošiem faktoriem veikta dzimumstratificētā analīze $2 \times 2 \times \mathrm{k}$ tabulās, lai noteiktu divu faktoru saistību atšķirības dzimumu grupās. Aprēḳiniem izmantota Mantela-Hansela (angl. Mantel-Haenszel) metode, kuras nulles hipotēze nosaka, ka nav izredžu attiecību atšḳirības dzimumu grupās. Nulles hipotēze noraidīta gadījumos, ja MantelaHansela testa $p$ vērtība ir mazāka par 0,05 (McDonald, 2014).

Daudzfaktoru loǵistiskajā regresijā analizēta dažādu vardarbības veidu ietekme uz jauniešu veselību raksturojošajiem parametriem - veselības pašvērtējumu, sūdzībām par psihoemocionālo veselību, pārmērīgu alkohola lietošanu un pašnāvības mēǵinājumiem. Asociācija starp bērnībā pieredzēto vardarbību un veselību raksturojošajiem parametriem samērota ar respondenta dzimuma un gimeni raksturojošajiem faktoriem. Katram vardarbības veidam veikta atsevišķa daudzfaktoru regresijas analīze.

Regresijas modelī iekḷautajiem neatkarīgajiem mainīgajiem tika veikta kolinearitātes (angl. - collinearity) pārbaude, lai noteiktu, vai neatkarīgajām pazīmēm nav pārāk cieša savstarpējā korelācija. Daudzfaktoru regresijas modeḷos iekḷaujamo mainīgo izvēlei izmantota mērķtiecīgās izvēles (angl. purposeful selection) metode. Sākotnēji noteikta katra mainīgā saistība ar iznākumu, izmantojot vienfaktora regresijas analīzi. Regresijas modeḷos iekḷauti tie mainīgie, kuru $\mathrm{p}$ vērtība $<0,025$. Šāds $\mathrm{p}$ vērtības atdalīšanas punkts (nevis vispār pieņemtais 0,05$)$ noteikts, lai modelī tiktu iekḷauti visi nozīmīgie regresijas modeḷa neatkarīgie mainīgie. Tāpat regresijas modeḷos pārbaudīta jaucējfaktora ietekme, par jaucējfaktoru pieņemot to mainīgo, kuru samērojot ar citiem regresijas modelī iekḷautajiem mainīgajiem, novēro izredžu attiecības izmaiņas vismaz par 15\% (Bursac, Gauss, Williams and Hosmer, 2008). Regresijas modeḷos pārbaudīta neatkarīgo mainīgo multiplikatīvā mijiedarbība ar citiem neatkarīgajiem mainīgajiem. 
Visiem statistiskajiem testiem noteikts būtiskuma līmenis (p) 0,05. Rezultāti atzīti par statistiski ticamiem, ja p vērtība bija mazāka par 0,05. Datu analīzei izmantotas datorprogrammas MS Excel un IBM SPSS.

\subsection{Kvalitatīvās pētniecības daḷa}

\subsubsection{Datu ieguve}

Pētījuma kvalitatīajvā daḷā, lai noskaidrotu ekspertu pieredzi darbā ar vardarbībā cietušajiem bērniem kā informācijas iegūšanas instruments izmantotas padziḷinātas, dal̦ēji strukturētas ekspertu (psihoterapeitu, psihologu un ārstu psihoterapeitu) intervijas. Kvalitatīvais pētījums pievērš uzmanību procesiem, būtībai un strukturālām fenomena raksturiezīmēm un palīdz pētniekam iedziḷināties pētāmajā fenomenā (Flick, Kardoff and Steinke, 2004). Empīriskajā sociālajā pētniecībā ekspertu intervijas ir piemērots un bieži izmantots instruments, kas palīdz pētniekam izprast pētniecības nozares galvenās problēmas un sniedz kontekstuālu nozares raksturojumu. Promocijas darbā ekspertu intervijas ir kā papildu informācijas avots, kas sniedz kontekstuālas zināšanas par mērḳa grupu, t.i., vardarbībā cietušajiem bērniem (Bogner and Menz, 2009).

Ekspertu interviju jautājumu protokolu veidoja trīs jautājumu sadaḷas. Pirmajā sadaḷā ekspertiem tika vaicāts par to, kāda ir cietušo bērnu vardarbības pieredze un kā bērni izprot vardarbību kā fenomenu. Otrajā jautājumu sadaḷā tika noskaidrota ekspertu pieredze attiecībā uz sekām, kādas vardarbība atstāj uz cietušo veselību. Trešajā sadaḷā tika noskaidrots ekspertu viedoklis par to, kādas vardarbības izraisīto traucējumu pārvarēšanas stratēgiijas cietušie bērni izmanto, un kāda ir institūciju darbības loma šajā procesā. 
Ekspertu interviju veikšanai tika saņemta Rīgas Stradiṇa universitātes Ẽtikas komitejas atḷauja. Veicot intervijas ar ekspertiem, tika ievēroti kvalitatīvās pētniecības êtikas pamatprincipi - informētā piekrišana, konfidencialitāte un atbildība par pētniecības sekām (Rohleder et al., 2015). Ekspertu piekrišana dalībai pētījumā bija balstīta uz brīvprātības principu. Lai nodrošinātu atbildīgu izturēšanos pret pētnieciskā darba potenciālajām nelabvēlīgajām sekām uz pētîjuma dalībniekiem, datu ieguvei tika izvēlēts veikt intervijas ar ekspertiem, nevis ar bērniem, kuri cietuši no vardarbības, jo cietušo bērnu intervēšana rada vardarbīgā notikuma retraumatizācijas risku.

\subsubsection{Atlase un respondentu raksturojums}

Intervijas ar ekspertiem tika veiktas laika periodā no 2013. gada 29. novembrim līdz 2014. gada 20. janvārim. Kopumā tika intervēti 14 eksperti. Atlasot ekspertus intervijām, tika izmantota maksimālās dažāaības atlase (Patton, 2002), lai iegūtu informāciju no ekspertiem ar dažādu darba pieredzi. Galvenais atlases kritērijs bija ekspertu darba pieredze ar vardarbībā cietušajiem bērniem, kā arī viṇa piekrišana sniegt interviju. Intervējamo ekspertu dažādības nodrošināšanai noteikti šādi papildu atlases kritēriji:

- specialitāte: psihologi, psihoterapeiti un ārsti psihoterapeiti;

- darbavieta: valsts, pašvaldības vai privāta;

- ǵeogrāfiskais pārklājums: dažādas Latvijas pilsētas un novadi.

Sākotnējā ekspertu rekrutēšana tika balstīta uz sarakstu, kurā apkopoti psihologi, psihoterapeiti un sociālie darbinieki, kas apguvuši apmācību programmu psihologiem, psihoterapeitiem un sociālajiem darbiniekiem no vardarbības cietušo bērnu rehabilitācijai. Intervijās piedalījās eksperti, kuri strādā šādās Latvijas pilsētās: Rīgā, Ventspilī, Talsos, Jūrmalā, Valmierā, Daugavpilī. Visas intervijas notika ekspertu darbavietās. Vidējais intervijas 
ilgums bija 1 stunda 6 minūtes. İsākā intervija ilga 38 minūtes, bet garākā nevis vispār pieņemtais 0,05 1 stundu un 49 minūtes. Interviju audiofaili tika transkribēti. Interviju transkripcijas tika veiktas laika periodā no 2013. gada 1. decembra līiz 2014. gada 24. februārim.

\subsubsection{Datu apstrādes metode}

Interviju datu apstrādē izmantota tematiskā analīzes metode, ar kuras palīdzību tiek identificētas, analizētas un interpretētas vienotas informācijas nozīmes jeb tēmas kvalitatīvajos datos. Datu kodēšana veikta manuāli. Intervijas datu kodēšana paredz kodu jeb vienotu apzīmējumu piešķiršanu līdzīgām saturiskām frāzēm kopējā tekstā. Kods ietver sevī pamata analītisko ideju atbilstoši pētījuma tēmai (Braun, Clarke and Terry, 2015). Iegūtie kodi tika apvienoti tēmās, kuras tika pakārtotas atbilstoši interviju jautājumu protokola trim sadaḷām - cietušo bērnu vardarbības pieredze un vardarbības jēdziena izpratne, vardarbības sekas uz veselību, vardarbības izraisīto traucējumu pārvarēšanas stratēgijas un institūciju darbības loma.

Tematiskā analīze veikta pēc sešu soḷu ietvarstruktūras (Braun and Clarke, 2006).

1. Iepazī̌sanās ar iegūtajiem datiem. Intervijas tika transkribētas un notika interviju transkripciju lasīšana un pārlasīšana.

2. Sākotnējo kodu piešķiršana. Lasot tekstu, tika pieškirti sākotnējie kodi, kas balstīti uz sarunu kontekstu.

3. Tēmu meklēšana. Šajā posmā notika jau plašāka interpretatīvā analīze un līdzīgie kodi tika apvienoti sākotnējās tēmās.

4. Tēmu pārskatīšana. Sākotnējās tēmas pēc vajadzības apvienotas vai, gluži pretēji, sadalītas, nodrošinot saskaņotību (iekšējo homogenitāti) un 
skaidri nosakāmas atšķirības (ārējo heterogenitāti). Iegūto rezultātu strukturēšanai un vizuālai attēlošanai izveidota tēmu karte.

5. Tēmu definēšana. Katrā tēmā tika identificēta galvenā ideja jeb doma, veicot tēmu "attīīišanu un pārdefinēšanu".

6. Ziņojuma rakstīšana. Šajā posmā notika iegūto tēmu aprakstī̌sana, izmantojot atbilstošus citātus no ekspertu intervijām. 


\section{KVANTITATĪVĀ PēTĪJUMA REZULTĀTI}

\subsection{Vardarbības izplatība un vardarbības veidu savstarpējās sakarības}

No visiem respondentiem $56,0 \%(\mathrm{n}=578)$ atzīmēja, ka ir pieredzējuši vismaz vienu vardarbības veidu. Lai gan sievietes kopumā vardarbību pieredzējušas biežāk nekā vīrieši (attiecīgi 58,4\% $(\mathrm{n}=308)$ sieviešu un 53,5\% ( $\mathrm{n}=270)$ vīriešu), dzimumatšķirības nav statistiski nozīmīgas $(\mathrm{p}>0,05)$. Visus vardarbības veidus, izņemot emocionālo nevērību, biežāk pieredzējušas sievietes, tomēr statistiski nozīmīgas atšķirības dzimumu grupās novēro tikai bērnībā pieredzētajai seksuālajai vardarbībai (sk. 3.1. tab.).

3.1. tabula

Vardarbības veidu prevalence dzimumu grupās, \%

\begin{tabular}{|l|r|r|r|r|c|c|}
\hline \multirow{2}{*}{\multicolumn{1}{|c|}{ Vardarbības veidi }} & \multicolumn{4}{|c|}{ Vīrieši } & \multicolumn{3}{c|}{ Sievietes } \\
\cline { 2 - 7 } & \multicolumn{1}{c|}{$\mathrm{n}$} & \multicolumn{1}{c|}{$\%$} & \multicolumn{1}{c|}{$95 \% \mathrm{TI}$} & \multicolumn{1}{c|}{$\mathrm{n}$} & \multicolumn{1}{c|}{$\%$} & $95 \% \mathrm{TI}$ \\
\hline Fiziska vardarbība & 90 & 14,9 & $12,2-17,9$ & 108 & 17,9 & $15,0-21,1$ \\
\hline Emocionāla vardarbība & 170 & 28,0 & $24,6-31,7$ & 212 & 35,1 & $31,4-29,0$ \\
\hline Seksuāla vardarbība & 36 & 6,8 & $5,0-9,3$ & 74 & 13,7 & $11,1-16,9$ \\
\hline Emocionāla nevērība & 144 & 24,0 & $20,8-27,6$ & 141 & 23,5 & $20,3-27,1$ \\
\hline Fiziska nevērība & 155 & 26,1 & $22,7-29,8$ & 165 & 28,0 & $24,5-31,8$ \\
\hline
\end{tabular}

Daḷa respondentu ir pieredzējuši vairāk nekā tikai vienu no vardarbības veidiem. 16,0\% $(\mathrm{n}=165)$ ir pieredzējuši divus vardarbības veidus, 8,9\% $(\mathrm{n}=$ $92)$ - trīs vardarbības veidus, $4,7 \%(n=48)$ respondentu bērnībā ir pieredzējuši četrus vardarbības veidus, bet $0,8 \%(n=8)$ ir pieredzējuši visus piecus vardarbības veidus.

Visas korelācijas starp fiziskās, emocionālās, seksuālās vardarbības un fiziskās un emocionālās nevērības veidiem bija statistiski nozīmīgas. Korelācijas 
koeficients uzrādīja nenozīmīgu saistību $(\mathrm{r}<0,30)$ starp analizētajiem vardarbības veidiem, izņemot fizisko un emocionāluo vardarbību $(r=0,49)$ un emocionālo un fizisko nevērību $(r=0,32)$, kuru gadījumā novērojama vāja pozitīva saistība.

\subsection{Bērn̄̄bā pieredzētās vardarbības saistība ar g̊imeni raksturojošiem faktoriem}

Respondentu sadalījums grupās pēc ǵimenes SES ir šāds: 29,4\% $(\mathrm{n}=356)$ respondentu ğimenes SES ir zems, 37,2\% $(\mathrm{n}=451)$ respondentu vidējs, bet 33,4\% (n=405) - augsts. Statistiski nozīmīgas sakarības ar ǵimenes SES līmeni novēro tikai fiziskas vardarbības un emocionālas nevērības gadījumos. Jauniešiem, kuru gimeņu SES ir zems ir 1,4 (95\% TI = 1,0-2,1) reizes lielākas izredzes pieredzēt fizisko vardarbību un 1,6 (95\% TI $=1,1-2,2)$ reizes lielākas izredzes pieredzēt emocionālo nevērību salīdzinājumā ar jauniešiem, kuru gimenes SES ir augsts.

Vecāku šķiršanos vai dzīvošanu atsevišķi pieredzējuši 42,3\% $(n=513)$ no visiem respondentiem. Tiem jauniešiem, kuru vecāki ir bijuši šķīrušies vai dzīvojuši atsevišḳi novēro 2,0 (95\% TI = 1,4-3,0) reizes lielākas izredzes bērnībā pieredzēt seksuālo vardarbību, 1,4 (95\% TI = 1,0-1,9) reizes lielākas izredzes ciest no fiziskās vardarbības un 1,5 (95\% TI $=1,2-1,9)$ reizes lielākas izredzes pieredzēt emocionālo vardarbību nekā tiem jauniešiem, kuru vecāki nav šķīrušies vai dzīvojuši atsevišķi. Statistiski ticamu asociāciju starp vecāku šķiršanos vai dzīvošanu atsevišḳi un emocionālo un fizisko nevērību nenovēro.

Izredzes pieredzēt fizisko, emocionālo un seksuālo vardarbību gadījumā, ja vecāki ir šḳīrušies vai dzīvo atsevišķi ir dzimumspecifiskas. Vīriešiem vecāku šķiršanās vai dzīvošanas atsevišķi gadījumā ir lielākas izredzes pieredzēt fizisko un emocionālo vardarbību nekā sievietēm. Savukārt sievietēm, kuru vecāki ir šḳīušiies vai dzīvojuši atsevišḳi ir 1,9 $(95 \% \mathrm{TI}=1,2-3,2)$ reizes lielākas izredzes 
pieredzēt seksuālo vardarbību nekā sievietēm, kuru vecāki nav šḳīrušies vai dzīvojuši atsevišķi, bet vīriešiem šī asociācija nav statistiski nozīmīga. Fiziskās un emocionālās nevērības saistība ar bērnu vecāku šķiršanos vai dzīvošanu atsevišḳi nav dzimumspecifiska.

Tēva vai mātes partnera vardarbību pret māti pieredzējuši $12,6 \%$ $(\mathrm{n}=152)$ no aptaujas dalībniekiem. Tēva vardarbība pret māti vairākas reizes palielina pret bērnu vērstas vardarbības izredzes. Ja ğimenē notiek vardarbība pret māti, bērna izredzes pieredzēt emocionālu vardarbību ir 5,6 (95\% TI = 3,9-8,1) reizes lielākas nekā gadījumos, kad vardarbība pret māti gimenē nenotiek. Ģimenēs, kurās notiek vardarbība pret māti, novērotas arī augstas fiziskās vardarbības (OR = 4,9 (95\% TI = 3,4-7,1)) un emocionālās nevērība (OR = 3,9 (95\% TI = 3,4-7,1) izredzes bērniem.

Ģimenēs, kurās bērni piedzīvo vardarbību starp pieaugušajiem gímenes locekḷiem, biežāk notiek arī vardarbība pret bērniem, taču pastāv cietušo dzimumatškirīibas. Seksuālās vardarbības $(\mathrm{OR}=3,0 ; 95 \%$ TI $=1,7-5,3)$ un emocionālās nevērības (OR $=4,4 ; 95 \%$ TI $=2,8-6,6)$ izredzes gimenēs, kurās notiek tēva vardarbība pret māti, ir augstākas sieviešu populācijā. Attiecībā uz seksuālo vardarbību dzimumu grupas nav homogēnas $\left(\chi^{2}=8,3\right.$; $\left.\mathrm{p}<0,05\right)$. Vīriešu grupā ir tikai viens respondents, kurš bērnībā gimenē ir pieredzējis gan seksuālo vardarbību, gan tēva vardarbību pret māti, un tas ir pārāk mazs respondentu skaits, lai veiktu asociāciju analīzi starp abiem mainīgajiem. Vīriešiem gimenēs, kurās notiek tēva vardarbība pret māti, ir lielākas izredzes ciest no fiziskās $\quad(\mathrm{OR}=6,9 ; \quad 95 \% \quad \mathrm{TI}=3,8-12,8), \quad$ emocionālās $(\mathrm{OR}=6,4 ; \quad 95 \% \quad \mathrm{TI}=2,4-6,3) \quad$ vardarbības $\quad$ un fiziskās $\quad(\mathrm{OR}=3,7$; $95 \%$ TI = 2,0-6,6) nevērības nekā vīriešiem, kuru ǵimenēs tēvs nav vardarbīgs pret māti.

Pārmērīgu alkohola lietošanu ǵimenē kopumā norādījuši 44,1\% respondentu. Pastāv sakarības starp pārmērīgu alkohola lietošanu gimenē un vardarbību pret bērnu. Tiem jauniešiem, kuru gimenē pārmērīgi tiek lietots 
alkohols bija $3(\mathrm{OR}=3,0 ; 95 \% \mathrm{TI}=2,4-3,9)$ reizes lielākas izredzes pieredzēt emocionālo vardarbību un 1,5-2 reizes lielākas emocionālās nevērības, seksuālās un fiziskās vardarbības pieredzes izredzes.

Asociācija starp bērnībā pieredzēto vardarbību un pārmērīgu alkohola lietošanu dzimumu grupās atšķiras fiziskās, emocionālās, seksuālās vardarbības un emocionālās nevērības gadījumos, savukārt fiziskās nevērības pret bērnu saistība ar pārmērīgu alkohola lietošanu vīriešiem un sievietēm nav atšḳirīga $(\chi 2=2,7 ; p>0,05)$. Lielākas izredzes pieredzēt vardarbību gimenēs, kurās notiek pārmērīga alkohola lietošana, ir sievietēm. Vislielākās izredzes meitenēm ǵimenēs, kurās notiek pārmērīga alkohola lietošana, ir pieredzēt emocionālo (OR = 3,2; 95\% $\mathrm{TI}=2,3-4,6)$ un seksuālo vardarbību $(\mathrm{OR}=2,2 ; 95 \%$ TI = 1,3-3,8), salīdzinot ar sievietēm, kuru gimenēs nenotiek pārmērīga alkohola lietošana.

Psihiskās veselības problēmas gimenē norādījuši 19,3\% $(n=235)$ respondentu. Psihiskās veselības problēmu esamība gimenē vairākas reizes palielina izredzes, ka bērni pieredzēs kādu no vardarbības veidiem. Visaugstākās izredzes novēro fiziskās $(\mathrm{OR}=4,3$ 95\% TI = 3,1-6,0) un emocionālās (OR = 4,0; 95\% TI = 3,0-5,4) vardarbības gadījumā. Vīriešiem izredzes pieredzēt vardarbību gadījumos, kad gimenē ir kāds, kuram ir psihiskās veselības problēmas, ir augstākas nekā sievietēm. Vīriešiem, kas auguši ğimenē kopā ar kādu, kuram ir psihiskās veselības problēmas, lielākas izredzes ir pieredzēt fizisko vardarbību $(\mathrm{OR}=4,7 ; 95 \% \mathrm{TI}=3,0-7,3)$ un emocionālo nevērību $(\mathrm{OR}=4,4 ; 95 \% \mathrm{TI}=$ 2,9-6,6) salīdzinājumā ar vīriešiem, kuru ğimenēs šādu problēmu nebija. Savukārt sievietēm, kuru gimenēs ir psihiskās veselības problēmas, novēro augstākās izredzes saskarties ar fizisko un emocionālo vardarbību nekā sievietēm, kuru ǵimenēs nav novērotas psihiskās veselības problēmas. 


\subsection{Jauniešu veselību un ğimeni raksturojošie faktori}

Veselības pašvērtējums parāda respondentu subjektīvo savas veselības vērtējumu. Laba veselības pašvērtējuma grupā respondentu īpatsvars ir 80,4\% $(n=967)$, bet slikta pašvērtējuma grupā - 19,3\% $(n=236)$. Dzimumu grupās novēro statistiski ticamas atšķirības $(\chi 2=3,7 ; p<0,001)$. No visiem vīriešiem $87,4 \%(\mathrm{n}=527)$ vērtēja savu veselību kā labu, bet no visām sievietēm tikai 73,3\% ( $\mathrm{n}=440)$. Veselības pašvērtējums ir saistīts arī ar jauniešu ǵimeni raksturojošiem faktoriem. Lielāks īpatsvars to jauniešu, kuri vērtē savu veselību kā sliktu, ir dzīvojuši gimenēs ar zemu SES. Slikta veselības pašvērtējuma izredzes jauniešiem no gimenēm ar zemu SES ir 1,7 (95\% TI = 1,2-2,4) reizes lielākas nekā jauniešiem no ğimenēm ar augstu SES, savukārt starp jauniešiem, kuru ğimenēs ir vidējs un augsts SES, atšķirības slikta veselības pašvērtējuma izredzēm nenovēro. Arī vecāku šķiršanās vai dzīvošana atsevišķi $(O R=1,8$; $95 \%$ TI $=1,4-2,5)$ un tēva/partnera vardarbība pret māti $(\mathrm{OR}=1,9$; 95\% TI = 1,3-2,8) nelabvēlīgi ietekmē jauniešu veselības pašvērtējumu. Tāpat jauniešiem, kuru ǵimenē notiek pārmērīga alkohola lietošana, ir 2,1 (95\% TI = 1,5-2,7) augstākas slikta veselības pašvērtējuma izredzes nekā jauniešiem, kuru gimenēs šīs problēmas nav. Arī psihiski nevesela ǵimenes locekḷa dzīvošana gimenē asociēta ar sliktāku jauniešu veselības pašvērtējumu. Tiem, kuru ǵimenē ir psihiskās veselības problēmas, slikta veselības pašvērtējuma izredzes ir 2,5 $(95 \%$ TI $=1,8-3,5)$ reizes augstākas nekā tiem jauniešiem, kuru ǵimenēs šādu problēmu nav.

No visiem aptaujātajiem jauniešiem 45,1\% $(\mathrm{n}=548)$ norādīja, ka pēdējā mēneša laikā nevienu reizi nav piedzērušies, bet 54,9\% $(\mathrm{n}=667)$ bijuši piedzērušies vismaz vienu reizi. Vīrieši pēdējā mēneša laikā piedzērušies biežāk nekā sievietes, attiecīgi 62,1\% $(n=378)$ vīriešu un 47,7\% $(n=289)$ sieviešu. Atšķirības dzimumu grupās ir statistiski nozīmīgas $(\chi 2=25,4 ; \mathrm{p}<0,001)$. 
Salīdzinājumā ar jauniešiem, kas dzīvo gimenēs, kuru SES ir zems, pārmērīga alkohola lietošana ir izplatītāka to jauniešu vidū, kuri dzīvo ǵimenēs ar augstu un vidēju SES, Asociāciju analīze liecina, ka jauniešiem, kuri dzīvo ǵimenē ar augstu SES, izredzes būt pakḷautiem pārmērīgai alkohola lietošanai pēdējā mēneša laikā ir lielākas nekā jauniešiem no gimenēm ar zemu SES $(\mathrm{OR}=0,7 ; 95 \%$ TI = 0,5-1,0). Savukārt pārējiem ǵimeni raksturojošajiem faktoriem (vecāku šķiršanās vai dzīvošana atsevišḳi, vardarbība pret māti, pārmērīga alkohola lietošana gimenē un psihiskās veselības problēmas gimenē) statistiski nozīmīgas atškirīibas saistībā ar jauniešu pārmērīgu alkohola lietošanu nenovēro $(p>0,05)$.

Psihoemocionālās veselības problēmas novērotas 31,6\% $(n=180)$ vīriešu un $42,4 \% \quad(n=250) \quad$ sieviešu. Atšķirīibas ir statistiski nozīmīgas $(\chi 2=14,5 ; \mathrm{p}<0,001)$. Psihoemocionālās veselības problēmu izplatībā ir vērojamas atškirīības visās ǵimeni raksturojošo faktoru grupās, izṇemot gimenes SES. Ja gímenē notikusi tēva vardarbība pret māti, psihiskās veselības problēmu sastopamības izredzes jauniešiem ir trīs reizes augstākas nekā tiem jauniešiem, kuru gimenē nav notikusi tēva vardarbība pret māti. Psihiskās veselības problēmu esamība kādam no gimenes locekḷiem arī trīs reizes paaugstina jauniešu psihoemocionālo veselības problēmu attīstības izredzes, bet pārmērīga alkohola lietošana gimenē asociēta ar 2,4 (95\% TI = 1,9-3,0) reizes lielākām psihoemocionālās veselības problēmu attīstības izredzēm jauniešiem.

No visiem respondentiem pašnāvības mēǵinājumus veikuši $6,1 \%$ $(n=74)$. No visiem vīriešiem pašnāvības mēginājumus ir veikuši 3,1\% (n = 19), bet sieviešu vidū šis īpatsvars ir augstāks - pašnāvības mēgininājumus veikušas $9,2 \%(\mathrm{n}=55)$ sieviešu. Atšḳirības dzimumu grupās ir statistiski nozīmīgas $(\chi 2=19,2 ; p<0,001)$. Vecums, kad pirmo reizi veikts pašnāvības mēǵinājums, variē no 11 līdz 20 gadiem. Vidējais vecums, kad pirmo reizi veikts pašnāvības mēginājums, ir 15,1 (standartnovirze 2,0) gads. 
Asociāciju analīzē starp ǵimenes SES un pašnāvības mēǵinājumiem novērojams, ka pašnāvības mēǵinājumu veikušo jauniešu īpatsvars ir augstāks gimenēs ar zemu SES - 7,7\% ( $n=27$; 95\% TI = 5,3-10,9) nekā ǵimenēs ar vidēju $(5,0 \%(\mathrm{n}=22 ; 95 \%$ TI $=3,3-7,4))$ un augstu SES $(6,2 \% \quad(\mathrm{n}=25$; 95\% TI $=4,2-9,0)$, tomēr atšķirības nav vērtējamas kā statistiski nozīmīgas. Analizējot pārējos gimeni raksturojošos faktorus, ir vērojamas statistiski nozīmīgas atšķirības attiecībā uz pašnāvības mēg̣inājumu veikušo jauniešu īpatsvaru. Augstāku pašnāvības mēǵinājumu izredzes novēro tiem jauniešiem, kuru vecāki ir bijuši šḳīušies vai dzīvojuši atsevišķi, kuru ǵimenē notikusi tēva vardarbība pret māti un ticis pārmērīgi lietots alkohols. Īpaši augstas pašnāvības mēǵinājumu izredzes ( $\mathrm{OR}=4,8 ; 95 \% \mathrm{TI}=3,0-7,8)$ novēro tajās ǵimenēs, kurās ir psihiskās veselības problēmas.

\subsection{Bērnībā pieredzētā vardarbība un jauniešu veselību raksturojošie parametri}

Asociāciju analīzes rezultāti liecina, ka atšķirības jauniešu veselības pašvērtējumā novēro arī vardarbību pieredzējušo un nepieredzējušo respondentu grupās. Tiem jauniešiem, kuri bērnībā pieredzējuši fizisko vardarbību un fizisko nevērību, ir attiecīgi 2,6 un 2,4 reizes lielākas sliktāka veselības pašvērtējuma izredzes nekā tiem jauniešiem, kuri šos vardarbības veidus nav pieredzējuši. Arī citu vardarbības veidu bērnības pieredze palielina sliktāka veselība pašvērtējuma izredzes jauniešu vecumā. Vienīgi bērnībā gūtas seksuālās vardarbības bērnības pieredzes saistība ar veselības pašvērtējumu jauniešu vecumā nav statistiski nozīmīga (sk. 3.2. tab.).

Daudzfaktoru logistiskās regresijas analīze liecina, ka sievietēm ir vairāk nekā divas reizes lielākas slikta veselības pašvērtējuma izredzes nekā vīriešiem. Šo sakarību novēro visos bērnībā pieredzēto vardarbības veidu regresijas modeḷos, izṇemot regresijas modeli, kurā iekḷauta seksuālā vardarbība $(\mathrm{OR}=1,0$ 
$(95 \%$ TI $=0,7-1,3))$. Aptuveni pusotru reizi augstākas sliktam veselības pašvērtējuma izredzes ir jauniešiem, kuru gimenes SES ir zems, salīdzinājumā ar jauniešiem, kuru ǵimenes SES ir augsts. Tāpat pusotru reizi augstākas slikta veselības pašvērtējuma izredzes ir jauniešiem, kuru vecāki ir šḳīrušies vai dzīvo atsevišķi un kuru ǵimenēs ir alkohola lietošanas problēmas, salīdzinājumā ar jauniešiem, kuru ǵimenēs šo problēmu nav. Psihiskās veselības problēmu esamība ǵimenē asociēta ar 1,7 - 2,2 reizēm (atkarībā no daudzfaktoru regresijas modelī iekḷautā vardarbības veida) lielākām slikta veselības pašvērtējuma izredzēm jauniešu vecumā nekā jauniešiem, kuru gimenēs psihiskās veselības problēmas nenovēro. Savukārt tēva vardarbība pret māti, daudzfaktoru regresijas modelī netika statistiski ticami asociēta ar jauniešu veselības pašvērtējumu.

\section{2. tabula}

Slikta veselības pašvērtējuma prevalence un izredžu attiecība saistībā ar pieredzētās vardarbības veidu

\begin{tabular}{|c|c|c|c|r|r|}
\hline \multicolumn{2}{|c|}{ Vardarbības veids } & \multicolumn{1}{c|}{$\mathrm{n}$} & $\%$ & OR 95\% TI & $\begin{array}{c}\text { Samērotais } \\
\text { OR 95\% TI }^{\mathrm{b}}\end{array}$ \\
\hline \multirow{2}{*}{ Fiziska vardarbība** } & $\mathrm{Ne}$ & 167 & 16,7 & 1,0 & 1,0 \\
\cline { 2 - 6 } & $\mathrm{Jā}$ & 67 & 34,5 & $2,6(1,9-3,7)$ & $2,2(1,5-3,2)$ \\
\hline \multirow{2}{*}{ Emocionāla vardarbība** } & $\mathrm{N} \overline{\mathrm{e}}$ & 126 & 15,4 & 1,0 & 1,0 \\
\cline { 2 - 6 } & $\mathrm{J} \overline{\mathrm{a}}$ & 108 & 28,6 & $2,2(1,7-3,0)$ & $1,6(1,2-2,3)$ \\
\hline \multirow{2}{*}{ Seksuāla vardarbība } & $\mathrm{Ne \overline { }}$ & 178 & 18,8 & 1,0 & 1,0 \\
\cline { 2 - 6 } & $\mathrm{Jā}$ & 27 & 24,5 & $1,4(0,9-2,2)$ & $1,2(0,7-1,9)$ \\
\hline \multirow{2}{*}{ Emocionāla nevērība** } & $\mathrm{N} \overline{\mathrm{e}}$ & 146 & 16,1 & 1,0 & 1,0 \\
\cline { 2 - 6 } & $\mathrm{Jā}$ & 88 & 31,2 & $2,4(1,7-3,2)$ & $2,2(1,6-3,2)$ \\
\hline \multirow{2}{*}{ Fiziska nevērība** } & $\mathrm{N} \overline{\mathrm{e}}$ & 146 & 17,1 & 1,0 & 1,0 \\
\cline { 2 - 6 } & $\mathrm{Jā}$ & 85 & 27,0 & $1,8(1,3-2,4)$ & $1,8(1,3-2,5)$ \\
\hline
\end{tabular}

$* \mathrm{p}<0,05$

$* * \mathrm{p}<0,001$

${ }^{a}$ Izredžu attiecība aprēkināta katram vardarbības veidam atsevišḳi

b Izredžu attiecība aprēḳināta katram vardarbības veidam atsevišḳi un samērota ar respondentu dzimumu, ǵimenes SES, vecāku šķiršanos, tēva vardarbību pret māti, pārmērīgu alkohola lietošanu un psihiskās veselības problēmām ǵimenē 
Izredzes jauniešu pārmērīgai alkohola lietošanai fiziskās vardarbības pieredzes gadījumā, samērojot ar respondenta dzimumu, ir 1,4 (95\% TI = 1,0-2,0) reizes lielākas nekā tiem jauniešiem, kuri fizisko vardarbību nav pieredzējuši. Savukārt emocionālās vardarbības bērnības pieredzes gadījumā pārmērīgas alkohola lietošanas izredzes jauniešu vecumā ir 1,2 (95\% TI = 1,0-1,6) reizes lielākas nekā tiem jauniešiem, kuri šo vardarbības veidu nav pieredzējuši (sk. 3.3. tab.). Pārmērīgas alkohola lietošanas izredzes jauniešu vecumā ir atšķirīgas dzimumu grupās. Vīriešiem ir 1,8 $(95 \% \mathrm{TI}=1,5-2,3)$ reizes lielākas pārmērīgai alkohola lietošanas izredzes nekā sievietēm, turklāt šīs izredzes nemainās, neatkarīgi no tā, vai asociācija tiek samērota ar fiziskās vai emocionālās vardarbības pieredzi.

3.3. tabula

Pārmērīga alkohola lietošanas prevalence un izredžu attiecība saistībā ar pieredzētās vardarbības veidu

\begin{tabular}{|c|c|c|c|r|r|}
\hline \multicolumn{2}{|c|}{ Vardarbības veids } & \multicolumn{1}{c|}{$\mathrm{n}$} & $\%$ & OR $(95 \% \mathrm{TI})^{\mathrm{a}}$ & $\begin{array}{c}\text { Samērotais } \\
\text { OR (95\% TI) }\end{array}$ \\
\hline \multirow{2}{*}{ Fiziska vardarbība* } & $\mathrm{N} \overline{\mathrm{e}}$ & 540 & 53,7 & 1,0 & 1,0 \\
\cline { 2 - 6 } & $\mathrm{Jā}$ & 121 & 61,4 & $1,4(1,0-1,9)$ & $1,4(1,0-2,0)$ \\
\hline \multirow{2}{*}{ Emocionāla vardarbība } & $\mathrm{N} \overline{\mathrm{e}}$ & 442 & 53,7 & 1,0 & 1,0 \\
\cline { 2 - 6 } & $\mathrm{Jā}$ & 218 & 57,4 & $1,2(1,0-1,6)$ & $1,2(1,0-1,6)$ \\
\hline \multirow{2}{*}{ Seksuāla vardarbība } & $\mathrm{N} \overline{\mathrm{e}}$ & 521 & 54,8 & 1,0 & 1,0 \\
\cline { 2 - 6 } & $\mathrm{Jā}$ & 63 & 57,3 & $1,1(0,7-1,7)$ & - \\
\hline \multirow{2}{*}{ Emocionāla nevērība } & $\mathrm{Ne}$ & 497 & 54,6 & 1,0 & - \\
\cline { 2 - 6 } & $\mathrm{Ja}$ & 174 & 55,0 & $1,0(0,8-1,3)$ & - \\
\hline \multirow{2}{*}{ Fiziska nevērība } & $\mathrm{Ne}$ & 469 & 54,6 & 1,0 & - \\
\cline { 2 - 6 } & $\mathrm{Jā}$ & 174 & 54,9 & $1,0(0,8-1,3)$ & \\
\hline
\end{tabular}

$* \mathrm{p}<0,05$

${ }^{a}$ Izredžu attiecība aprēḳināta katram vardarbības veidam atsevišḳi

b Izredžu attiecība aprēḳināta katram vardarbības veidam atseviški un samērota ar respondentu dzimumu 
Gan vienfaktora asociāciju analīze, gan daudzfaktoru regresijas analīze liecina, ka psihoemocionālās veselības problēmas jauniešu vecumā ir saistītas ar bērnībā pieredzēto vardarbību. Tiem jauniešiem, kuri bērnībā pieredzējuši fizisko vardarbību, ir 3,6 (95\% TI = 2,6-5,0) reizes lielākas psihoemocionālās veselības problēmu attīstības izredzes, bet tiem, kuri pieredzējuši emocionālu vardarbību - 3,3 (95\% TI = 2,6-4,3) reizes lielākas izredzes (sk. 3.4. tab.).

3.4. tabula

Psihoemocionālās veselības problēmu prevalence un izredžu attiecība saistībā ar bērnībā pieredzēto vardarbības veidu

\begin{tabular}{|c|r|c|c|r|r|}
\hline \multicolumn{2}{|c|}{ Vardarbības veids } & \multicolumn{1}{c|}{$\mathrm{n}$} & $\%$ & OR $(95 \% \mathrm{TI})^{\mathrm{a}}$ & $\begin{array}{c}\text { Samērotais } \\
\text { OR }(95 \% \mathrm{TI})^{\mathrm{b}}\end{array}$ \\
\hline \multirow{2}{*}{ Fiziska vardarbība** } & $\mathrm{N} \overline{\mathrm{e}}$ & 310 & 32,1 & 1,0 & 1,0 \\
\cline { 2 - 6 } & $\mathrm{Jā}$ & 118 & 63,1 & $3,6(2,6-5,0)$ & $2,6(1,8-3,7)$ \\
\hline \multirow{2}{*}{ Emocionāla vardarbība** } & $\mathrm{N} \overline{\mathrm{e}}$ & 220 & 28,1 & 1,0 & 1,0 \\
\cline { 2 - 6 } & $\mathrm{Ja}$ & 208 & 56,4 & $3,3(2,6-4,3)$ & $2,3(1,7-3,0)$ \\
\hline \multirow{2}{*}{ Seksuāla vardarbība* } & $\mathrm{N} \overline{\mathrm{e}}$ & 323 & 35,0 & 1,0 & 1,0 \\
\cline { 2 - 6 } & $\mathrm{Jā}$ & 49 & 46,7 & $1,6(1,1-2,4)$ & $1,3(0,8-1,9)$ \\
\hline \multirow{2}{*}{ Emocionāla nevērība** } & $\mathrm{N} \overline{\mathrm{e}}$ & 278 & 31,7 & 1,0 & 1,0 \\
\cline { 2 - 6 } & $\mathrm{Jā}$ & 146 & 55,1 & $2,7(2,0-3,5)$ & $2,1(1,5-2,8)$ \\
\hline \multirow{2}{*}{ Fiziska nevērība* } & $\mathrm{N} \overline{\mathrm{e}}$ & 296 & 35,6 & 1,0 & 1,0 \\
\cline { 2 - 6 } & $\mathrm{Ja}$ & 128 & 43,2 & $1,4(1,1-1,8)$ & $1,1(0,9-1,5)$ \\
\hline
\end{tabular}

$* \mathrm{p}<0,05$

$* * \mathrm{p}<0,001$

a Izredžu attiecība aprēḳināta katram vardarbības veidam atsevišḳi

b Izredžu attiecība aprēķināta katram vardarbības veidam atsevišķi un samērota ar respondentu dzimumu, vecāku šķiršanos, tēva vardarbību pret māti, pārmērīgu alkohola lietošanu un psihiskajām veselības problēmām ǵimenē

Samērojot šo asociāciju ar respondenta dzimumu un gimeni raksturojošajiem faktoriem, asociācijas ciešums vājinās un ir attiecīgi 2,6 reizes fiziskās vardarbības un 2,3 reizes emocionālās vardarbības gadījumā. Seksuālās vardarbības un fiziskās nevērības bērnības pieredze vienfaktoru analīzē saistīta 
ar augstākām psihoemocionālās veselības problēmu attīstības izredzēm jauniešiem, bet daudzfaktoru analīzē tā kḷūst statistiski nenozīmīga (sk. 3.4. tab.).

3.5. tabula

Pašnāvības mēg̣inājumu prevalence un izredžu attiecība saistībā ar pieredzēto vardarbības veidu

\begin{tabular}{|c|c|c|c|c|c|}
\hline \multicolumn{2}{|l|}{ Vardarbības veids } & $\mathrm{n}$ & $\%$ & OR 95\% $\mathrm{TI}^{\mathrm{a}}$ & $\begin{array}{c}\text { Samērotais } \\
\text { OR }(95 \% \text { TI })^{\mathrm{b}}\end{array}$ \\
\hline \multirow{2}{*}{ Fiziska vardarbība** } & $\mathrm{Nē}$ & 40 & 4,0 & 1,0 & 1,0 \\
\hline & $\mathrm{Jā}$ & 34 & 17,4 & $5,1(3,1-8,3)$ & $3,7(2,1-6,2)$ \\
\hline \multirow{2}{*}{ Emocionāla vardarbība** } & $\mathrm{Nē}$ & 31 & 3,8 & 1,0 & 1,0 \\
\hline & $\mathrm{Ja}$ & 43 & 11,4 & $3,3(2,0-5,3)$ & $2,2(1,3-3,7)$ \\
\hline \multirow{2}{*}{ Seksuāla vardarbība* } & $\mathrm{Nē}$ & 55 & 5,8 & 1,0 & 1,0 \\
\hline & $\mathrm{Jā}$ & 13 & 11,8 & $2,2(1,1-4,1)$ & $1,1(0,5-2,2)$ \\
\hline \multirow{2}{*}{ Emocionāla nevērība** } & $\mathrm{Ne \overline { }}$ & 31 & 3,4 & 1,0 & 1,0 \\
\hline & $\mathrm{Jā}$ & 43 & 15,4 & $5,1(3,-8,3)$ & $4,0(2,3-6,8)$ \\
\hline \multirow{2}{*}{ Fiziska nevērība** } & $\mathrm{Ne \overline { }}$ & 39 & 4,6 & 1,0 & 1,0 \\
\hline & $\mathrm{Jā}$ & 33 & 10,4 & $2,4(1,5-3,9)$ & $2,2(1,3-3,7)$ \\
\hline
\end{tabular}

$* \mathrm{p}<0,05$

$* * \mathrm{p}<0,001$

a Izredžu attiecība aprēḳināta katram vardarbības veidam atsevišḳi

b Izredžu attiecība aprēķināta katram vardarbības veidam atsevišķi un samērota ar respondentu dzimumu, vecāku šķiršanos, tēva vardarbību pret māti, pārmērīgu alkohola lietošanu un psihiskajām veselības problēmām ǵimenē

Fiziskās vardarbības un emocionālās nevērības pieredze tiek asociēta ar piecas reizes lielākām pašnāvības mēginājumu izredzēm salīdzinājumā ar tiem respondentiem, kuri šos vardarbības veidus nav pieredzējuši. Bērnībā gūta emocionālās vardarbības pieredze tiek asociēta ar 3,3 (95\% TI =2,0-5,3) reizes lielākām pašnāvības mēginājumu izredzēm, fiziska nevērība ar 2,4 (95\% TI = 1,5-3,9) reižu lielākām izredzēm, bet seksuāla vardarbība ar 2,2 (95\% $\mathrm{TI}=1,1-4,1)$ reizes lielākām pašnāvības mēǵinājumu izredzēm. Samērojot asociāciju ar respondenta dzimumu un ǵimeni raksturojošajiem faktoriem, 
saistības ciešums starp bērnībā pieredzēto vardarbību un pašnāvības mēǵinājumu veikšanu vēlākā dzīves periodā vājinājās, bet bērnībā gūtā seksuālās vardarbības pieredze saistībā ar pašnāvības mēginājumu veikšanu vairs neuzrādīja savstarpēju asociāciju (sk. 3.5. tab.). 


\section{KVALITATĪVĀ PĒTĪJUMA REZULTĀTI}

\subsection{Cietušo bērnu vardarbības pieredze un vardarbības jēdziena izpratne}

\subsubsection{Vardarbības jēdziena konceptualizācijas dažādība}

Pēc interviju kodēšanas jautājumu sadaḷā par cietušo vardarbības pieredzi un vardarbības jēdziena izpratni iezīmējās trīs tēmas - vardarbības jēdziena konceptualizācijas dažādība, bērnu vardarbības pieredzes raksturojums un bērnu atklātība par pieredzēto vardarbību. Ekspertu pieredze liecina, ka bērnu izpratne par pieredzēto vardarbību nav pilnīga. Tā kā vardarbība pret bērniem visbiežāk notiek ǵimenē, situācijas objektīvu uztveri apgrūtina bērna emocionālā piesaiste ǵimenes locekliem, kā arī ambivalentās jūtas pret pāridarītāju. Savas ǵimenes vidi bērns uztver kā pašsaprotamu, līdz ar to viņš šādi saredz arī tajā notiekošos procesus un cilvēku uzvedību, tai skaitā vardarbību. Bērna spēja analizēt un salīdzināt savu ǵimeni ar citu cilvēku gímenēm sāk attīstīties pusaudžu vecumā. Eksperti novērojuši, ka bērniem ir nepiln̄̄ga izpratne par vardarbību kā konceptuālu jēdzienu, tomēr vinịi norāda, ka vardarbība bērnu vidū tiek atpazīta situatīvi kā darbība vai kā situācija. Daži eksperti norādīja, ka dažkārt ir saskārušies ar gadījumiem, kad bērni vardarbību izmanto kā instrumentu manipulācijām ar pieaugušajiem.

\subsubsection{Bērnu vardarbības pieredzes raksturojums}

Visbiežāk bērni, kas nonākuši intervēto ekspertu redzeslokā, cietuši no emocionālās vardarbības. Kā otrs biežāk pieredzētais vardarbības veids norādīta nevērība pret bērnu. Visretāk bērni cietuši no seksuālās vardarbības, tomēr šis 
vardarbības veids parasti atstāj vissmagākās sekas uz bērna turpmāko veselību. Ekspertu pieredze liecina, ka bērni bieži vien pieredz vairāk nekā tikai vienu vardarbības veidu, turklāt vardarbības veidu savstarpējās kombinācijas mēdz būt dažādas. Kā biežākie pāridarītāji norādīti bērna ǵimenes locekḷi, un tas skaidrojams kā vecāku varas pārkāpums pret bērnu.

\subsubsection{Cietušā bērna atklātība par notikušo vardarbību}

Bērna spēja atklāti runāt par notikušo vardarbību ekspertu pieredzē ir dažāda. Daḷa ekspertu norādīja, ka atklātāk par notikušo vardarbību runā jaunāka vecuma bērni un meitenes. Būtiska nozīme ir arī laikam, kas pagājis pēc pieredzētās vardarbības, - jo ātrāk notikušais ir pamanīts, jo vieglāk bērns spēj par to pastāstīt. Kā galvenos iemeslus bērna klusēšanai eksperti min potenciālu bērna liecības ietekmēšanu un vardarbīgā vai arī nevardarbīgā vecāka manipulācijas ar cietušo bērnu. Tāpat spēju atklāti runāt par notikušu vardarbību var ietekmēt bērna izjūtas - kauns, vaina vai bailes.

\subsection{Vardarbības ietekme uz veselību}

\subsubsection{Ietekme uz fizisko un psihoemocionālo veselību}

Vardarbība atstāj nelabvēlīgas sekas uz cietušā bērna veselību gan īstermiņā un ilgtermiṇā. Vardarbībai var būt dažāda veida fiziskās sekas uz bērna veselību - traumas un ievainojumi, slimības, nevēlama grūtniecība. Visās intervijās eksperti norādīja uz psihosomatiskiem un kognitīviem traucējumiem, kas radušies pārciestās vardarbības izraisītā stresa dēḷ. Bērna uzvedības un psihoemocionālie traucējumi tiek raksturoti kā eksternalizēti vai internalizēti psihiskās veselības traucējumi, no kuriem pirmajiem raksturīga agresīva un 
antisociāla uzvedība, bet otrajiem - zems pašvērtējums, trauksme un depresīvs noskaņojums. Tāpat no vardarbības cietušajiem bērniem novēro grūtības socializēties un veidot normālas, sociāli pieņemamas attiecības ar līdzcilvēkiem.

\subsubsection{Veselību ietekmējošie faktori}

Vairākās intervijās eksperti norādīja, ka ilgtermiņā daudzveidīgākās sekas uz bērnu atstāj emocionālā vardarbība, bet kā otrs vardarbības veids, kas atstāj vissmagākās sekas, tika pieminēta seksuālā vardarbība. Fiziskā vardarbība pret bērnu bieži vien tika klasificēta kā mazāk kaitīga bērna veselībai ilgākā laika periodā. Nozīme ir arī tam, cik ilgi notikusi vardarbība, - vai tā ir bijusi viena epizode vai ilgstoši un atkārtoti notikumi. Vardarbības epizodes, kuras ir ilgstošākas un atkārtojas, atstāj smagākas sekas uz bērna veselību. Vardarbības atstātās sekas uz veselību atkarīgas arī no paša bērna resursiem, personības un intelekta attīstības pakāpes, kā arī no biologiskiem faktoriem, piemēram, iedzimtības.

\subsection{Vardarbības izraisīto traucējumu pārvarēšanas stratēgeijas, institūciju darbības loma}

\subsubsection{Traucējumu pārvarēšanas stratēǵiju raksturojums}

Bērnu reakcija uz vardarbības pieredzi ir dažāda. Dažkārt bērni notikušajā vaino sevi, bet citkārt var novērot pretēju, uz āru vērstu reakciju - dusmas un agresiju, īpaši zēniem. Tāpat nereti sastopams reakcijas veids ir notikušās vardarbības noliegšana un izstumšana no apziņas. Vardarbības izraisīto traucējumu pārvarēšanas pozitīva stratēg̣ija ir gadījumos, kad paši cietušie bērni meklē palīdzību un atbalstu, tomēr eksperti norāda, ka tas viṇu pieredzē notiek 
reti. Biežāk cietušajiem bērniem novēro negatīvās vardarbības izraisīto traucējumu pārvarēšanas stratēgijas, kas izpaužas kā devianta uzvedība, vispārpieņemto sociālo lomu pārkāpšana, pārmērīga atkarību izraisošo vielu lietošana, pašsakropḷošanās un pašnāvības mēginājumi.

\subsubsection{Darbs ar cietušo bērnu}

Lai mazinātu vardarbību un nodrošinātu sekmīgu cietušā bērna rehabilitāciju pēc notikušas vardarbības, būtiska nozīme ir savlaicīgai vardarbības gadījumu atklāšanai. Ekspertu pieredze liecina, ka ne vienmēr vardarbība tiek konstatēta tūlīt pēc vardarbīgā notikuma. No vardarbīgā notikuma līdz tā atklāšanai var paiet laiks - no dažām dienām līdz pat vairākiem gadiem. Vardarbību pret bērnu var atpazìt pēc bērna uzvedības izmaiņām vai àrējām izpausmēm. Skolas un sociālie dienesti ir tās institūcijas, kas visbiežāk pamana iespējamos vardarbības gadījumus un ziņo par tiem, savukārt ārstniecības personas ziṇo salīdzinoši reti.

Pamata priekšnosacījumi sekmīgai rehabilitācijai pēc pārdzīvotas vardarbības bērnam ir atbalsts un drošība. Būtiskākais ir atbalsts no bērna gimenes, tomēr to sniegt var arī citi pieaugušie - radinieks, skolotājs, treneris un citi. Nozīmīga ir arī atbalsta forma: svarīgi ir noticēt bērna stāstītajam, viṇu pieņemt un nenosodīt. Profesionāla palīdzība bērnam jāsaņem no psihologa vai psihoterapeita, kas var objektīvi izvērtēt notikušo un palīdzēt bērnam tikt galā ar vardarbības stresa izraisītajiem traucējumiem. Kā rehabilitācijas vājās puses eksperti norādīja gadījumus, kad bērni cieš no institūciju darbības. Lai gan cietušajiem bērniem būtu jāsaņem atbalsts un palīdzība no dažāda veida institūcijām (sociālā dienesta, policijas, bāriņtiesas u.c.), realitātē saskarsme ar šiem speciālistiem dažkārt izraisa vēl lielāku kaitējumu un psihoemocionālo traumu. Kā visbiežākie riski norādīti speciālistu neatsaucība un vājas 
profesionālās prasmes, institūciju sistēmiskas un ilgstošas darbības trūkums pret bērniem vērstās vardarbības gadījumu risināšanā, kā arī konfidencialitātes neievērošana un informācijas noplūde.

\subsubsection{Rehabilitācijas sistēmiskās vajadzības}

Svarīgs resurss no vardarbības cietušo bērnu rehabilitācijā ir labi apmācīti speciālisti un to pieejamība. Apmācības nepieciešamas dažādu nozaru speciālistiem, kuri ir iesaistīti pret bērnu vērstās vardarbības gadījumu atklāšanā un risināšanā. Sekmīgai pret bērnu vērstās vardarbības gadījumu risināšanai nepieciešama starpinstitucionāla sadarbība. Tie eksperti, kuri savā darbā ir pieredzējuši šāda veida sadarbību, rezultātus novērtēja kā pozitīvus.

Papildus jau esošajām programmām un pakalpojumiem būtu jānodrošina atbalsta programmas ne tikai cietušajam bērnam, bet bērna gimenei kopumā, jo nereti bērnu vecākiem trūkst zināšanu un izpratnes par vardarbību pret bērnu. Tāpat sistēmiskai pret bērniem vērstās vardarbības gadījumu risināšanai būtu jānodrošina palīdzības programmas varmākam, lai novērstu jaunus potenciālus vardarbības gadījumus pret to pašu bērnu vai citu personu. Nozīmīgi ir veikt preventīvos pasākumus vardarbības mazināšanai, piemēram, sabiedrības, vecāku izglītošanu par vardarbību pret bērniem, stingrāku seksuālas vardarbības noziedznieku uzraudzību u. c. Lai pasargātu bērnu vardarbības gadījuma izmeklēšanā, svarīgi, lai likumiskais regulējums paredzētu, ka mājvieta jāatstāj vardarbīgajai personai, nevis cietušajam bērnam. Būtiska nozīme ir arī operatīvai bērna liecību sniegšanai un ierakstîšanai pēc iespējas īsākā laika periodā pēc notikušās vardarbības, lai ierakstītā liecība būtu izmantojama izmeklēšanas procesā un lai novērstu bērna liecības ietekmēšanu no citu personu puses. Attiecībā uz cietušo bērnu rehabilitāciju eksperti norādīja, ka būtu ieteicams diferencēt terapijas ilgumu cietušajiem bērniem, katru gadījumu izvērtējot 
individuāli un rūpīgi izsverot, vai ir nepieciešama bērna ievietošana krīzes centrā. Pēc iespējas biežāk jācenšas nodrošināt bērna atstāšanu ierastajā vidē un rehabilitācijas pakalpojumu sniegšanu dzīvesvietā. 


\section{DISKUSIJA}

Pirmā promocijas darbā izvirzìtā hipotēze, kas noteica, ka pastāv sakarības starp gimeni raksturojošiem faktoriem un bērnībās pieredzētās vardarbības veidiem jauniešu dzimumu grupās, ir apstiprinājusies. Starp dažādiem ǵimeni raksturojošajiem faktoriem un vardarbību pret bērniem tika novērotas statistiski nozīmīgas sakarības (sk. 5.1. tabulu). Savukārt otra hipotēze, kas paredzēja, ka ir vērojamas atšķirības jauniešu veselību raksturojošajos parametros starp jauniešu grupām ar dažādu bērnībā gūtās vardarbības pieredzi, apstiprinājās daḷēji (sk. 5.1. tabulu). Tika konstatēts, ka pastāv saistība starp jauniešu veselību raksturojošajiem parametriem un bērnībā pieredzēto fizisko un emocionālo vardarbību un nevērību, bet ne starp veselību raksturojošajiem parametriem un bērnībā pieredzēto seksuālo vardarbību.

Emocionālās vardarbības prevalence Latvijas jauniešu populācijā ir augstāka nekā citās valstīs, bet bērnībā pieredzētās emocionālās nevērības rādītāji ir līdzīga līmeņa vai pat zemāki. Promocijas darbā iegūtie rezultāti sakrīt ar 2004. gadā publicētā pētîjuma rezultātiem par emocionālās un fiziskās vardarbības izplatības rādītāju salīdzinājumu pusaudžiem un jauniešiem četrās Baltijas un Austrumeiropas valstīs (Sebre et al., 2004). Arī šajā pētījumā Latvijas populācijā bija vieni no augstākajiem emocionālās vardarbības pieredzes rādītājiem starp visā pētījumā iesaistītajām valstīm. Citu valstu pêtījumos par bērnībā gūto nelabvēlīgo pieredzi emocionālās vardarbības prevalence ir zemāka nekā Latvijas jauniešu populācijā: ASV - 10,3\% (Dube et al., 2006), Lielbritānijā - 17,3\% (Bellis et al., 2014) un Nīderlandē - 12,9\% (Enns et al., 2006). Emocionālās nevērības prevalence (23,6\%) Latvijā ir augstāka nekā ASV veiktajā pētījumā (14,8\%) (Dube et al., 2006), bet līdzịga līmeṇa kā Nīderlandē veiktajā pêtījumā (25,2\%) (Enns et al., 2006). 2013. gadā publicētajā meta-analīzes pētîjumā apkopoja 16 pētījumu rezultātus par pašu respondentu 
ziṇoto bērnībā pieredzētās nevērības prevalenci. Apkopotais emocionālās nevērības prevalences rādītājs bija $18,4 \%$, bet fiziskās nevērības prevalences rādītājs - 16,3\%. Gan emocionālās, gan fiziskās nevērības prevalence Latvijas jauniešu populācija ir augstāka, attiecīgi 23,6\% un 27,0\%.

Emocionālā vardarbība un nevērība ir viena no grūtāk atpazīstamajām vardarbības formām, jo nodarītais kaitējums nav tūlītēji pamanāms un nelabvēlīgās sekas izpaužas tikai ilgākā laika periodā. Emocionālā vardarbība pret bērnu kā atsevišķa vardarbības forma definēta salīdzinoši nesen - apmēram pirms 25 gadiem (Cindy and Miller-Perrin, 2013), līdz ar to pētniecība un izpratne par šo vardarbības veidu ir salīdzinoši nesen formējusies. Tāpat emocionālās vardarbības izpausmes un līdz ar to arī atpazīstamība var atšķirties dažādās sabiedrībās. Kā liecina Baltijas un Austrumeiropas valstīs veiktā pētījuma rezultāti par fizisko un emocionālo vardarbību pret bērniem, ir vērojamas atšķirības pat starp Latviju un Lietuvu, kas teritoriāli atrodas viena otrai blakus. Attiecībā uz vecāku emocionālās vardarbības pret bērnu izpausmēm Lietuvā biežāk novērota aktīvā emocionālās vardarbības forma - kliegšana uz bērnu, bet Latvijas populācijā vecāki biežāk izmanto pasīvo emocionālās vardarbības formu, kura izpaužas kā vecāku rīcība, kas liek bērnam sajusties vainīgam. Arī citos pētījumos ir pierādīts, ka emocionālās vardarbības formas ir būtiski pētīt kā atsevišķu pret bērniem vērstās vardarbības veidu, jo tās var atstāt smagas un ilgtermiṇā nelabvēlīgas sekas uz bērna veselību un labklājīibu (McCabe, 2003; Crosson-Tower, 1999; Rose \& Fife, 2012). Ekspertu pieredze darbā ar vardarbībā cietušajiem bērniem liecina, ka emocionālā vardarbība un nevērība pret bērnu ir starp tiem vardarbības veidiem, no kuriem bērni cietuši visbiežāk, turklāt šo vardarbības veidu pieredze būtiski ietekmē cietušo labklājību ilgtermiṇā. Fakts, ka Latvijas jauniešu populācijā emocionālās vardarbības un nevērības prevalences rādītāji ir augstāki, nekā citviet veiktajos pētījumos, kā arī zinātniskajā literatūrā pieejamā informācija par šo vardarbības veidu nelabvēlīgo ietekmi uz turpmāko fizisko, psihisko un sociālo veselību 
norāda uz nepieciešamību veikt šo vardarbības veidu mazināšanas aktivitātes Latvijas sabiedrībā.

Bērnībā pieredzētās fiziskās vardarbības prevalence Latvijas jauniešu populācijā (16,3\%) ir zemāka nekā līdzīgā pētìjumā ASV (26,7\%) (Dube et al., 2006), bet augstāka nekā atsevišḳās Eiropas valstīs - Lielbritānijā (14,3\%) (Bellis et al., 2014), Nīderlandē (8,7\%) (Enns et al., 2006) un Zviedrijā (15,2\%) (Annerback, Wingren, Svedin and Gusstafsson, 2010). Iespējams, šīs atškirīības var skaidrot ar fizisko sodu legiitimitātes atšḳirībām dažādās valstīs. Piemēram, Zviedrijā jebkāda veida fizisko sodu izmantošana bērnu audzināšanā ir aizliegta kopš 1979. gada (Pinheiro, 2006), bet Latvijā to aizliedza tikai 1998. gadā. Savukārt ASV ir vien̄̄gā ANO dalībvalsts, kas nav ratificējusi Bērnu tiesību konvenciju (1989), un ASV joprojām nav pilnībā aizliegta bērnu fiziskā sodīšana audzināšanas nolūkos. Attieksme pret fizisko sodu izmantošanu bērnu disciplinēšanas nolūkos arī varētu būt viens no faktoriem, kas ietekmē pret bērniem vērstās fiziskās vardarbības izplatību. Pētījumos ir apkopota informācija par dažādiem sabiedrību raksturojošiem faktoriem, kas veicina fizisko sodu izmantošanu. Tie ir šādi: vardarbības leǵitimitāte un akceptēšana sabiedrībā, nevienlīdzība sabiedrībā un ǵimenē, kultūrvēsturiskas pārliecības par fizisko sodu nepieciešamību un nekaitīgumu, lauksaimniecības un industriālās sabiedrības modelis pretstatā pēcindustriālās sabiedrības modelim (Straus, 2010). Arī Latvijas sabiedrībā vēl joprojām daḷa iedzīvotāju ir atbalstoši noskaņoti pret fizisko sodu izmantošanu bērnu audzināšanas nolūkos. Rezultāti, kas iegūti aptaujā par Latvijas iedzīvotāju attieksmi pret vardarbību pret bērniem, liecina, ka aptuveni puse respondentu uzskatīja bērnu sišanu kā sodīšanas veidu dažkārt var pielietot, savukārt aptuveni trešdą̧a respondentu uzskatīja, ka bērnu fizisku sodīšanu drīzāk nevajadzētu aizliegt ar likumu (Pirsko, 2010).

Literatūras analīze liecina, ka bērnībā pieredzētās seksuālās vardarbības prevalence variē no 7,0\% (Enns et al., 2006) līdz 21,3\% (Bellis et al., 2014). Metaanalīzes pētījumā, kurā apkopoti 217 pêtījumu rezultāti par bērnībā 
pieredzēto seksuālo vardarbību, apkopotais seksuālās vardarbības prevalences rādītājs bija 11,8\% (Stoltenborgh, van IJzendoorn, Euser and BakermansKranenburg, 2011). Tas ir tuvu bērnībā pieredzētās seksuālās vardarbības prevalences rādītājam Latvijas jauniešu populācijā - 10,4\%. Skaidrojumi bērnībā pieredzēto vardarbības veidu prevalences atškirībām pētījumu populācijās ir dažādi. Rādītāju variāciju var ietekmēt arī atškirīibas pētījumu metodologiijā, piemēram, pētîjumā izmantotā gadījuma definīcija, mērījumiem izmantotās skalas un novērtēšanas instrumenti. Pierādīts, ka seksuālās vardarbības prevalence plaši variē atkarībā no pētījuma gadījuma definīcijā iekḷautajām seksuālā pāridarījuma formām. Metaanalīzes pētījumā apkopotais prevalences rādītājs, ja seksuālās vardarbības definīcijā ietverta jebkāda veida seksuālās vardarbības izpausmes, bija 25,3\% meitenēm un 8,7\% zēniem, bet, sašaurinot definīciju tikai uz seksuālās vardarbības gadījumiem ar penetrāciju, prevalence bija attiecīgi 5,3\% meitenēm un 1,9\% zēniem (Ezzati, Lopez, Rodgers and Murray, 2004). Nozīme var būt arī pētījumā izmantotajam datu avotam. Populāciju aptaujās par bērnībā pieredzēto vardarbību tiek iegūti aptuveni desmit reizes augstāki rādītāji nekā liecina bērnu aizsardz̄̄bas institūciju ziņoto gadījumu apmērs (Fergusson, Horwood and Woodward, 2000; MacMillan, Jamieson and Walsh, 2003). Tas norāda, ka seksuāls pāridarījums vairākumā gadījumu tiek slēpts un līdz ar to palielinās iespējamība tam atkārtoties.

Ģimenēs, kurās notiek vardarbība pret bērniem, tiek atrastas sakarības ar dažādiem gimenes vidi raksturojošajiem faktoriem. To apliecina arī Bronfenbrennera sociāli ekoloǵiskā teorija (Bronfenbrenner, 1979). Ar̄̄ promocijas darbā starp dažādiem ǵimeni raksturojošiem faktoriem un bērnībā pieredzēto vardarbību atrastas statistiski nozīmīgas sakarības (sk. 5.1. tab.).

Viena no promocijas darba hipotēzēm paredzēja, ka ir novērojamas atšķirības jauniešu veselību raksturojošajos parametros atkarībā no bērnībā gūtās vardarbības pieredzes. Pamatojoties uz Latvijas jauniešu veselības un ar veselību saistītās uzvedības aktualitātēm sabiedrības veselības skatījumā, kā arī 
zinātniskos pētījumos gūtiem pierādījumiem, tika izvēlēti šādi veselības parametri: jauniešu veselības pašvērtējums, pārmērīga alkohola lietošana, sūdzības par psihoemocionālo veselību un pašnāvības mēǵinājumi. Tie veselības iznākumi, kuriem novēroja statistiski nozīmīgas sakarības ar bērnībā pieredzēto vardarbību, apskatāmi 5.1. tabulā.

Pierādījumi, kas iegūti neirobiolog̣ijas pētījumos skaidro mehānismus, kādā veidā bērnībā gūtā nelabvēelīgā pieredze var atstāt sekas uz bērna psihisko un fizisko attīstību un veicināt ilgtermiņa veselības problēmu attīstību, savukārt epidemioloǵiskie pētījumi, kas veikti plašās populācijās, pierāda šīs sakarības esamību populācijas līmen̄i. Lai gan daži pētījumi ir veikti kā prospektīvi kohortu pētîjumi un tajos ir pierādīta kauzālā saistība starp bērnībā gūto nelabvēlīgo pieredzi un veselības traucējumiem vēlākā dzīves periodā, daudzos pētījumos, tajā skaitā promocijas darba pētījumā, izmantota pieaugušo respondentu aptauja par notikumiem bērnībā. Jānem vērā, ka šāds pētījuma dizains var būt saistīts ar atcerēšanās sistemātisko novirzi (Sklzo and Nieto, 2014), proti, tie, kuri ir pieredzējuši vardarbību, var tikt nepareizi klasificēti kā vardarbību nepieredzējuši, vai otrādi. Līdz ar to atcerēšanās novirze var ietekmēt patieso saistības ciešumu starp bērnībā pieredzēto vardarbību un veselību raksturojošajiem parametriem jauniešu vecumā. Lai pārbaudītu respondentu pašu ziņoto bērnībā gūtās nelabvēlīgās pieredzes atbilžu pareizību, tika salīdzināta pētījumos retrospektīvi iegūto datu par bērnībā gūto nelabvēlīgo pieredzi sakritība ar objektīviem informācijas avotiem (oficiālajiem ierakstiem dokumentos, citu informācijas sniedzēju teikto). Secinājumos norādīts, ka pašu ziṇotā informācija ir pietiekami precīza un ir izmantojama, tomēr jārēkinās ar potenciālām sistemātiskajām novirzēm. Tāpat secināts, ka, izmantojot retrospektīvu respondentu aptauju, pastāv lielāka iespēja, ka, bērnībā pieredzētās vardarbības prevalences rādītājs tiks novērtēts kā zemāks nekā patiesībā (Hardt and Rutter, 2004). Tas liecina, ka bērnībā pieredzētās vardarbības gadījumu skaits varētu būt lielāks. 
5.1. tabula

Ģimeni raksturojošo faktoru un jaunieša veselības iznākumu saistība ar dažādiem bērnībā pieredzētajiem vardarbības veidiem

\begin{tabular}{|c|c|c|c|c|c|}
\hline \multirow{2}{*}{$\begin{array}{c}\text { Riska faktori } \\
\text { un veselības } \\
\text { iznākumi }\end{array}$} & \multicolumn{5}{|c|}{ Vardarbības veids } \\
\hline & $\begin{array}{c}\text { Fiziskā } \\
\text { vardarbība }\end{array}$ & $\begin{array}{l}\text { Emocionālā } \\
\text { vardarbība }\end{array}$ & $\begin{array}{c}\text { Seksuālā } \\
\text { vardarbība }\end{array}$ & $\begin{array}{c}\text { Emocionālā } \\
\text { nevērība }\end{array}$ & $\begin{array}{l}\text { Fiziskā } \\
\text { nevērība }\end{array}$ \\
\hline \multicolumn{6}{|c|}{ Gimenes riska faktori } \\
\hline Zems SES & $\sqrt{ }$ & & & $\sqrt{ }$ & \\
\hline $\begin{array}{l}\text { Vecāku } \\
\text { škirššanās }\end{array}$ & $\sqrt{ }$ & $\sqrt{ }$ & $\sqrt{ }$ & & \\
\hline $\begin{array}{c}\text { Tēva/partnera } \\
\text { vardarbība } \\
\text { pret māti }\end{array}$ & $\sqrt{ }$ & $\sqrt{ }$ & $\sqrt{ }$ & $\sqrt{ }$ & $\sqrt{ }$ \\
\hline $\begin{array}{c}\text { Pārmērīga } \\
\text { alkohola } \\
\text { lietošana }\end{array}$ & $\sqrt{ }$ & $\sqrt{ }$ & $\sqrt{ }$ & $\sqrt{ }$ & $\sqrt{ }$ \\
\hline $\begin{array}{c}\text { Psihiskās } \\
\text { veselības } \\
\text { problēmas }\end{array}$ & $\sqrt{ }$ & $\sqrt{ }$ & $\sqrt{ }$ & $\sqrt{ }$ & $\sqrt{ }$ \\
\hline \multicolumn{6}{|c|}{ Veselības iznākumi jauniešiem } \\
\hline $\begin{array}{c}\text { Sliktāks } \\
\text { veselības } \\
\text { pašvērtējums }\end{array}$ & $\sqrt{ }$ & $\sqrt{ }$ & & $\sqrt{ }$ & $\sqrt{ }$ \\
\hline $\begin{array}{c}\text { Pārmērīga } \\
\text { alkohola } \\
\text { lietošana }\end{array}$ & $\sqrt{ }$ & $\sqrt{ }$ & & & \\
\hline $\begin{array}{c}\text { Psihoemoc. } \\
\text { veselības } \\
\text { problēmas }\end{array}$ & $\sqrt{ }$ & $\sqrt{ }$ & & $\sqrt{ }$ & \\
\hline $\begin{array}{l}\text { Pašnāvības } \\
\text { mēǵinājumi }\end{array}$ & $\sqrt{ }$ & $\sqrt{ }$ & & $\sqrt{ }$ & $\sqrt{ }$ \\
\hline
\end{tabular}

$\sqrt{ }$ - novērotas statistiski nozīmīgas asociācijas starp mainīgajiem

Bērnībā gūtās nelabvēlīgās pieredzes pētījums ir veikts kā šḳērsgriezuma pētījums, kurā informācija no pētījuma dalībniekiem iegūta retrospektīvi. Jāṇem vērā, ka šāds pētījuma dizains neḷauj spriest par cēloṇu un seku sakarībām. Tāpat pētījuma rezultātus var ietekmēt sistemātiskā atcerēšanās kḷūda, pētījumā izmantotā gadījuma definīcija un datu ievākšanas instrumenti.

Lai iegūtu informāciju par vardarbībā cietušo bērnu rehabilitāciju, promocijas darbā ekspertiem tika uzdoti jautājumi par vardarbības izraisīto 
traucējumu pārvarēšanas stratẹgijām un dažādu institūciju darbību vardarbības atpazišanā un cietušo bērnu rehabilitācijas procesā. Lai mazinātu vardarbību pret bērniem un tās sekas, ir būtiski atpazìt vardarbības gadījumus, turklāt darīt to pēc iespējas savlaicīgāk, jo tā var nodrošināt sekmīgāku cietušo bērnu rehabilitāciju. Bērnu tiesību aizsardzības likuma (1998) 73. pants nosaka, ka pienākums ziņot par vardarbību pret bērnu policijai, bāriṇtiesai vai citai bērnu tiesību aizsardzības institūcijai ir katram iedzīvotājam un ka veselības aprūpes, pedagoǵiskie, sociālās sfēras vai policijas darbinieki, kā arī vēelētas valsts un pašvaldību amatpersonas, kuras ir zinājušas par bērnu tiesību pārkāpumu, bet nav par to ziņojušas institūcijām, ir saucamas pie atbildības likumā noteiktajā kārtībā. Eksperti savā pieredzē novērojuši, ka par vardarbības gadījumiem biežāk ziņo skolas un sociālie dienesti, kā arī apkārtējie iedzīvotāji, piemēram, cietušā bērna kaimiņi, taču salīdzinoši retāk to dara ārstniecības personas. Lai gan ir likumisks pamats veselības aprūpes speciālistu iesaistei pret bērniem vērstās vardarbības gadījumu atpazīšanā un informācijas nodošanā atbilstošajām institūcijām, prakse liecina, ka tas ne vienmēr tiek sekmīgi īstenots. Arī PVO rekomendācijās pret bērniem vērstās vardarbības mazināšanā norādīts, ka veselības aprūpes sektora darbiniekiem, īpaši primārās veselības aprūpes, neatliekamās palīdzības speciālistiem un pediatriem, ir būtiska loma vardarbības gadījumu atpazī̌anā, tādēḷ nepieciešams šos speciālistus apmācīt, kā atpazīt vardarbību pēc bērna ievainojumiem, slimībām un uzvedības un kā rīkoties, ja ir aizdomas par vardarbības gadījumu (WHO and International Society for Prevention and Child Abuse and Neglect, 2006). N̦emot vērā iepriekš minēto, lai sekmīgāk atpazītu pret bērniem vērstas vardarbības gadījumus, būtu jānoskaidro šḳēršlıi, kas kavē veselības aprūpes darbiniekus ziņot par vardarbību pret bērniem un jāmeklē atbistoši risinājumi.

Eksperti intervijās norādīja, ka rehabilitācijas procesā jānodrošina, lai bērnam būtu atbalsts, drošība un sakārtota dzīves vide ar paredzamu ikdienas režīmu. Vissvarīgākais atbalsts ir cietušā bērna ǵimene, tādēḷ palīdzības 
programmas nepieciešams piedāvāt arī cietušā bērna ǵimenes locekḷiem. Rehabilitācijas procesā bērnam nepieciešama arī profesionāla psihologa vai psihoterapeita palīdzība. PVO rekomendācijās pret bērniem vērstās vardarbības mazināšanā norādīts, ka pētījumos gūtie pierādījumi liecina - efektīvākās darbā ar vardarbībā cietušajiem bērniem ir kognitīvās un uzvedības maiņas metodes (WHO and International Society for Prevention and Child Abuse and Neglect, 2006). Tomēr ne vienmēr psihologiskās palīdzības pakalpojumu ir iespējams nodrošināt visiem cietušajiem bērniem. ASV pētījumā par psihologiskās palīdzības sniegšanas apjomu bērniem, kuri cietuši no vardarbības, secināts, ka pakalpojums nodrošināts tikai aptuveni pusei no visiem bērniem, kuriem tas ir nepieciešams (Petrenko, Culhane, Garrido and Taussig, 2011). Latvijā MK noteikumi Nr. 89 "Kārtība, kādā nepieciešamo palīdzību sniedz bērnam, kurš cietis no prettiesiskām darbībām” paredz, ka no vardarbības cietušajiem bērniem ir pieejami sociālās rehabilitācijas pakalpojumi dzīvesvietā (ne vairāk par desmit 45 minūšu konsultācijām) un sociālās rehabilitācijas institūcijā (kurss pieejams līdz 30 vai 60 dienām), tomēr ekspertu pieredze liecina, ka atsevišķos gadījumos cietušajiem bērniem būtu nepieciešama ilglaicīgāka psiholoǵiskās palīdzības un atbalsta nodrošināšana nekā šobrīd noteikts likumdošanā.

Kā būtisku aspektu sekmīgai pret bērniem vērstās vardarbības mazināšanā un cietušo bērnu atveseḷošanai eksperti norādīja starpdisciplināras prakses attīstīšanu un nodrošināšanu. Arī PVO rekomendācijas pret bērniem vērstās vardarbības mazināšanai paredz, ka ir nepieciešama multisektoriāla sadarbība starp izglītîbas, sociālās labklājības, tieslietu, veselības jomu un citām ieinteresētajām pusēm, kas pārstāv vietējo pārvaldi, ekspertus un nevalstiskās organizācijas (WHO, 2013a). Vardarbības gadījumu atklāšanā un cietušo bērnu rehabilitācijas procesā liela nozīme ir speciālistu profesionalitātei, zināšanām un izpratnei par vardarbību pret bērnu un tās izraisītajām sekām, tādēl ekspertu skatījumā ir nepieciešams apmācīt dažādu nozaru speciālistus par vardarbību pret bērniem, tās izpausmēm un sekām, kā arī profesionālu izturēšanos, sastopoties 
ar vardarbības gadījumiem. Ekspertu sniegtais viedoklis sakrīt ar PVO rekomendācijās minēto: arī tajās ir uzsvērta dažādu nozaru speciālistu izglītošanas un apmācības nozīme (Krug et al., 2002). 


\section{SECINĀJUMI}

1. Visbiežāk Latvijas jaunieši bērnībā ir pieredzējuši emocionālo vardarbību (31,5\%), fizisko $(27,0 \%)$ un emocionālo $(23,8 \%)$ nevērību, bet retāk - fizisko $(16,4 \%)$ un seksuālo $(10,3 \%)$ vardarbību.

2. Visus vardarbības veidus, izņemot emocionālo nevērību, biežāk pieredzējušas sievietes, tomēr statistiski nozīmīgas atšķirības dzimumu grupās novēro tikai bērnībā pieredzētās seksuālās vardarbības gadījumos (13,7\% sieviešu un $6,8 \%$ vīriešu).

3. Zems gimenes SES tiek asociēts ar 1,4 reizes lielākām fiziskās vardarbības un 1,6 reizes lielākā emocionālās nevērības izredzēm, salīdzinot ar jauniešiem no gimenēm ar augstu SES. Dzimumu grupās atšķirības netika novērotas.

4. Vecāku šḳiršanās vai dzīvošana atsevišḳi asociēta ar 1,4 reizes lielākām fiziskās vardarbības, 1,5 reizes lielākām emocionālās vardarbības un 2,0 reizes lielākām seksuālās vardarbības izredzēm salīdzinājumā ar jauniešiem, kuru vecāki nebija šķīrušies. Vīriešu vidū augstākas izredzes bija saskaroties ar emocionālo un fizisko vardarbību, bet sieviešu populācijā - ar seksuālo vardarbību.

5. Tēva vardarbība pret māti palielināja izredzes pieredzēt visus pret bērniem vērstās vardarbības pret bērniem veidiem - fizisko (OR =4,9), emocionālo $(\mathrm{OR}=5,6)$ un seksuālo $(\mathrm{OR}=2,4)$ vardarbību, emocionālo $(\mathrm{OR}=3,9)$ un fizisko $(\mathrm{OR}=2,9)$ nevērību, salīdzinot ar jauniešiem, kuru gimenēs vardarbība pret māti nenotika. Vīriešiem bija augstākas izredzes gūt fiziskās un emocionālās vardarbības un fiziskās nevērības pieredzi, bet sievietēm seksuālās vardarbības un emocionālās nevērības pieredzi.

6. Pārmērīga alkohola lietošana ǵimenē asociēta ar augstākām fiziskās vardarbības izredzēm $(\mathrm{OR}=2,0)$, emocionālās vardarbības izredzēm 
$(\mathrm{OR}=3,0)$, seksuālās vardarbības izredzēm $(\mathrm{OR}=1,9)$, kā arī emocionālās nevērības $(\mathrm{OR}=1,5)$ un fiziskās nevērības $(\mathrm{OR}=1,3)$ izredzēm. Augstākas visu vardarbības veidu izredzes novērotas sieviešu populācijā.

7. Psihiskās veselības problēmas gímenē asociētas ar 4,3 reizes lielākām fiziskās vardarbības izredzēm, 4,0 reizes lielākām emocionālās vardarbības izeredzēm, 2,4 reizes lielākām seksuālās vardarbības izredzēm, kā arī 3,3 reizes lielākām emocionālās nevērības un 1,4 reizes lielākām fiziskās nevērības izredzēm salīdzinājumā ar jauniešiem no gimenēm, kurās nebija psihiskās veselības problēmas. Visu vardarbības veidu gadījumā, izņemot fizisko nevērību, lielākas izredzes novēroja vīriešu populācijā.

8. Tiem jauniešiem, kuri bērnībā pieredzējuši kādu no vardarbības veidiem (izņemot seksuālo vardarbību), novēroja 1,2-2,2 reizes (atkarībā no modelī iekḷautā vardarbības veida) lielākas slikta veselības pašvērtējuma izredzes nekā jauniešiem bez vardarbības pieredzes. Asociācija samērota ar respondenta dzimumu un ǵimeni raksturojošajiem faktoriem.

9. Bērnībā pieredzēta fiziskā un emocionālā vardarbība asociēta ar 1,4 un 1,2 reizes lielākām pārmērīga alkohola lietošanas izredzēm jauniešu vecumā salīdzinājumā ar jauniešiem bez vardarbības pieredzes. Asociācija samērota ar respondenta dzimumu.

10. Tiem jauniešiem, kuri bērnībā pieredzējuši fizisko, emocionālo vardarbību un emocionālo nevērību, ir attiecīgi 2,6, 2,3 un 2,1 reizes lielākas psihiskās veselības problēmu attīstības izredzes jauniešu vecumā nekā jauniešiem bez šādas pieredzes. Asociācija samērota ar respondenta dzimumu un gimeni raksturojošajiem faktoriem.

11. Bērnībā pieredzēta vardarbība (izṇemot seksuālo vardarbību) asociēta ar 2,2-4,0 reizes lielākām pašnāvības mēǵinājumu izredzēm jauniešu vecumā salīdzinājumā ar jauniešiem bez vardarbības pieredzes, samērojot ar respondenta dzimumu un gimeni raksturojošajiem faktoriem. 
12. Vardarbības jēdziena izpratne cietušajiem bērniem ne vienmēr ir piln̄̄ga. Biežāk vardarbība tiek atpazìta kā darbība vai situācija, nevis kā fenomens, turklāt jēdziena izpratni ietekmē tādi bērnu raksturojoši faktori kā bērna vecums un izglītotība.

13. Pret bērniem vērstās vardarbības gadījumu savlaicīga atpazīšana atkarīga no vardarbības veida, bērna saistības ar varmāku, atbildīgo speciālistu un institūciju izglītotības un rīcības. Lai gan likumdošana paredz, ka ziṇošana par vardarbības gadījumiem pret bērniem ir obligāta, prakse liecina, ka salīdzinājumā ar citu nozaru speciālistiem ārstniecības personas par šiem gadījumiem ziņo reti.

14. No vardarbības cietušo bērnu rehabilitācijas procesā būtiska nozīme ir atbalsta, drošības un sakārtotas ikdienas dzīves vides, kā arī psiholoǵiskās palīdzības nodrošināšanai.

15. Pret bērniem vērstās vardarbības gadījumu atklāšanā un cietušo bērnu rehabilitācijas procesā jānodrošina multisektoriāla sadarbība un iesaistīto jomu speciālistu apmācības par vardarbību pret bērniem, tās izpausmēm un sekām, kā arī profesionālu izturēšanos, sastopoties ar vardarbības gadījumiem. 


\section{PRAKTISKĀS REKOMENDĀCIJAS}

1. Veselības aprūpes profesionāḷiem nepieciešams apgūt prasmes, kas pēc dažādām specifiskām pazīmēm palīdzētu pret bērniem vērstās vardarbības gadījumu atpazīšanā. Vardarbības veidi ir dažādi, tādēl ne vienmēr vardarbība atstāj fiziskās izmeklēšanas laikā pamanāmas sekas uz cietušā ķermeṇa. Pieredzētu vardarbību var atpazīt arī pēc citām pazīmēm, piemēram, bērna uzvedības un attīstības problēmām, tādēl būtiski ir apmācīt veselības aprūpē strādājošos speciālistus par vardarbībā cietušo bērnu fiziskās un psihoemocionālās veselības pazīmēm. N, Nemot vērā vardarbības negatīvo ietekmi uz bērna veselību ilgtermiṇā, būtiski ir šos gadījumus savlaicīgi atpazīt un ziņot par tiem atbildīgajām institūcijām. Savlaicīga gadījumu atpazīšana un palīdzības sniegšana sekmētu vardarbības izraisīto nelabvēlīgo seku, piemēram, psihoemocionālo veselības problēmu un pārmērīgas atkarības vielu lietošanas, mazināšanu jauniešu vecumā.

2. Sociālajiem darbiniekiem nepieciešams pievērst lielāku vērību ǵimenēm, kurās pastāv ǵimeni raksturojoši riska faktori - vardarbība pret māti, pārmērīga alkohola lietošana, psihoemocionālās veselības problēmas kādam gimenes loceklim, vecāku škiiršanās -, un proaktīvi rīkoties, lai laikus identificētu pret bērniem vērstās vardarbības gadījumus un palīdzētu koordinēt problēmas risināšanu starp atbildīgajām institūcijām.

3. Psihologiem un psihoterapeitiem nepieciešams iesaistīities pret bērniem vērstās vardarbības gadījumu izvērtēšanā un palīdzības sniegšanā, ņemot vērā bērna vajadzības un situācijas kontekstuālos faktorus, kā arī nodrošinot iegūtās informācijas konfidencialitāti. Psihoemocionālās rehabilitācijas procesā būtu jāpiedāvā pakalpojumi arī cietušā bērna ǵimenei. Iespēju robežās psihoemocionālās palīdzības saņemšanas ilgums jāpielāgo, katru gadījumu izvērtējot individuāli. 
4. Sabiedrības veselības politikas veidotājiem pret bērniem vērstas vardarbības novēršanai ir jāizvirza kā viena no valsts sabiedrības veselības prioritātēm. Sabiedrības veselības pieeja paredz uz pierādījumiem balstîtu un uz problēmas profilaksi vērstu pasākumu izstrādi un ieviešanu. Ṇemot vērā specifiskās uz pierādījumiem balstîtās sabiedrības veselības prasības un vardarbības ietekmi uz cietušo veselību gan īsākā, gan ilgākā laika periodā, vardarbības mazināšanas politikas izstrāde un vadība ir Veselības ministrijas kompetences jautājums. Arī PVO rekomendācijas vardarbības pret bērniem mazināšanai uzsver Veselības ministrijas kā koordinējošās institūcijas lomu vardarbības pret bērniem mazināšanā nacionālā mērogā. Nepieciešams veikt sistemātiskas un savstarpēji saskaņotas aktivitātes, lai risinātu pret bērniem vērstās vardarbības problēmu. Šīs aktivitātes ietver:

a. uzraudzību un datu vākšanu, lai apzinātu problēmas apmērus. Pētījums gūtie pierādījumi liecina, ka liela daḷa pret bērniem vērstās vardarbības gadījumu nav apzināti. Problēmas apmēra noskaidrošana nepieciešama, lai apzinātu mērḳa populāciju, kā arī ilgākā laika periodā izvērtētu ieviesto pasākumu efektivitāti;

b. datu analīzi un riska faktoru noteikšanu, lai identificētu no vardarbības cietušo bērnu vajadzības, vardarbības riska faktorus un faktorus, ko var izmantot vardarbības gadījumu mazināšanai;

c. intervences pasākumu izstrādi, kas pamatota uz pierādījumiem balstītā sabiedrības veselības prakses lēmumu pieņemšanā, kurā tiek ņemti vērā trīs pamatelementi - labākie pieejamie pierādījumi par efektīvu programmu, mērķa populācijas raksturojums pēc vajadzībām un vērtībām un pieejamie resursi (ieskaitot speciālistu resursus);

d. Pret bērniem vērstās vardarbības mazināšanas aktivitāšu ieviešanu un to ilgtspējības nodrošināšanu. Vardarbības mazināšanā liela loma ir sekmīgai starpnozaru sadarbībai. Veselības ministrijas kompetencē būtu koordinēt pret bērniem vērstās vardarbības mazināšanas politiku valstī un 
nodrošināt starpnozaru sadarbību. Svarīgi ir arī nodrošināt sabiedrības izglītošanu un dažādu nozaru speciālistu apmācību par vardarbību pret bērniem. 


\section{IZMANTOTĀ LITERATŪRA}

1. 14.04.2016. Par Jaunatnes politikas īstenošanas plānu 2016. - 2020.gadam: LR Ministru kabineta noteikumi Nr. 256. Latvijas Véstnesis. 74, 4.

2. 19.06.1998. Bērnu tiesību aizsardzības likums. Latvijas Vēstnesis. 199/200.

3. Anda, R.F., Felitti, V.J., Bremner, J.D., Walker, J.D., Whitfield, C., Perryn B.D., Shanta, R.D., Wayne, H.G. 2006. The enduring effects of abuse and related adverse experiences in childhood. A convergence of evidence from neurobiology and epidemiology. European Archives Psychiatry and Clinical Neuroscience. 256(3), 174-186.

4. Annerback, E.M., Wingren, G., Svedin, C.G., Gustafsson, P.A. 2010. Prevalence and characteristics of child physical abuse in Sweden - findings from a population-based youth survey. Acta Paediatrica. 99(8), 1229-1236.

5. Bellis, M.A., Hughes, K., Leckenby, N., Jonesm L., Babanm A., Kachaeva, M., Povilaitis, R., Pudule, I., Qirjako, G., Ulukol, B., Raleva, M., Terzic, N. 2014. Adverse childhood experiences and associations with health-harming behaviours in young adults: surveys in eight eastern European countries. Bulletin of the World Health Organization. 92(9), 641-655.

6. Bogner, A., Menz, W. 2009. The Theory-Generating Expert Interview: Epistemiological Interest, Forms of Knowledge, Interaction. In: Expert Interviewing. Bogner, A., Littig, B., Menz, W., eds. Basingstoke: Palgrave Macmillan.

7. Braun, V., Clarke, V. 2006. Using Thematic Analysis in Psychology. Qualitative Research in Psychology. 3(2), 77-101. Available from: doi: 10.1191/1478088706qp063oa [viewed 02.08.2016.]

8. Braun V, Clarke, V., Terry, G. 2015. Thematic analysis. In: Qualitative research in clinical and health psychology. Rohleder, P. and Lyons, A., eds. Basingstoke: Palgrave Macmillan.

9. Bronfenbrenner U. The ecology of human development. 1979. United States of America: Harvard University Press.

10. Bursac, Z., Gauss, CH., Williams, D.K., Hosmer, D.W. 2008. Purposeful selection of variables in logistic regression. Source Code for Biology and Medicine. 16(3), 17. Available from: doi: 10.1186/1751-0473-3-17 [viewed 14.11.2016]

11. Cindy, L. and Miller-Perrin, R.D.P. 2013. Child Maltreatment. An Introduction. 3 ed. United States of America: SAGE Publications.

12. Crosson-Tower, C. 1999. Understanding Child Abuse and Neglect. 4 ed. Boston: Allyn and Bacon.

13. Dube, S.R., Miller, J.W., Brown, D.W., Giles, W.H., Felitti, V.J., Dong, M., Anda R.F. 2006. Adverse childhood experiences and the association with ever using alcohol and initiating alcohol use during adolescence. Journal of Adolescent Health. 38(4), 444.e1-444.e10. Available from: https://doi.org/10.1016/j.jadohealth.2005.06.006 [viewed 04.05.2016]

14. Enns, M.W., Cox, B.J., Afifi, T.O., De Graaf, R., Ten Have, M., Sareen, J. 2006. Childhood adversities and risk for suicidal ideation and attempts: a longitudinal population-based study. Psychological Medicine. 36(12), 1769-1778. 
15. Erdoğan, S., Gülhan, O.T. 2016. Alternative Confidence Interval Methods Used in the Diagnostic Accuracy Studies. Computational and Mathematical Methods in Medicine. Available in: http://dx.doi.org/10.1155/2016/7141050 [viewed 02.11.206.]

16. Ezzati, M., Lopez, A.D., Rodgers, A., Murray, C.J.L. 2004. Comparative quantification of health risks: global and regional burden of disease attributable to selected major risk factors. Geneva: World Health Organization.

17. Fergusson, D.M., Horwood, L.J., Woodward, L.J. 2000. The stability of child abuse reports: a longitudinal study of the reporting behaviour of young adults. Psychological Medicine. 30(3), 529-544.

18. Gilbert, R, Widom, C.S., Browne, K., Fergusson, D., Webb, E., Janson, S. 2009. Burden and consequences of child maltreatment in high-income countries. Lancet. 373(9657), 68- 81.

19. Hardt, J., Sidor, A., Nickel, R., Kappis, B., Petrak, P., Egle, U. 2008. Childhood Adversities and Suicide Attempts: A Retrospective Study. Journal of Family Violence. 23(8), 713-718.

20. Krug, E.G., Dahlberg, L.L., Mercy, J.A., Zwi, A.B., Lozano, R. 2002. World report on violence and health. Geneva: World Health Organization.

21. LR Centrālā statistikas pārvalde. 2014. Jaunieši Latvijā. Rīga: LR Centrālā statistikas pārvalde.

22. MacMillan H.L., Fleming, J E., Streiner, D.L., Lin, E., Boyle, M.H., Jamieson, E., Duku, E.K., Walsh, C.A., Wong, M.Y., Beardslee, W.R. 2001. Childhood Abuse and Lifetime Psychopathology in a Community Sample. The American Journal of Psychiatry. 158, 1878-1883.

23. McCabe, K.A. 2003. Child abuse and the criminal system. United States: Peter Lang International Academic Publishers.

24. McDonald, J.H. 2014. Handbook of Biological Statistics. 3rd ed. Baltimore, Maryland: Sparky House Publishing.

25. Patton, G.C., Coffey, C., Romaniuk, H., Mackinnon, A., Carlin, J.B., Degenhardt, L., Olsson, C.A., Moran, P. 2014. The prognosis of common mental disorders in adolescents: a 14-year prospective cohort study. The Lancet. 383(9926), 1404-1411.

26. Petrenko, C.L.M., Culhane, S.E., Garrido, E..F, Taussig, H.N. 2011. Do youth in outof-home care receive recommended mental health and educational services following screening evaluations? Children and Youth Services Review. 33(10), 1911-1918.

27. Pirsko, L. 2010. Ziņojums par pētījuma rezultātiem. Iedzīvotāju attieksme pret vardarbību pret bērniem. Iegūts no: http://www.centrsdardedze.lv/data/ kampanas/Iedzivotaju_attieksme_pret_vardarbibu_2010.pdf [sk. 19.11.2016.]

28. Pinheiro P.S. 2006. World report on violence against children. Geneva: ATAR Roto Presse SA.

29. Rohleder, P., Smith, C. 2015. Ethical Issues. In: Qualitative research in clinical and health psychology. Rohleder, P. and Lyons, A., eds. Basingstoke: Palgrave Macmillan.

30. Rose, R.J., Dick, D.M., Viken, R.J., Pulkkinen, L., Kaprio, J. 2004. Genetic and environmental effects on conduct disorder and alcohol dependence symptoms and their covariation at age 14. Alcoholism: Clinical and Experimental Research. 28(10), 1541-1548.

31. Sebre, S., Sprugevica, I., Novotni, A., Bonevski, D., Pakalniskiene, V., Popescu, D., Turchina, T., Friedrich, W., Lewis, O. 2004. Cross-cultural comparisons of child- 
reported emotional and physical abuse: rates, risk factors and psychosocial symptoms. Child Abuse \& Neglect. 28(1), 113-127.

32. Sklzo, M., Nieto, F.J. 2014. Epidemiology. Beyond the Basics. 3rd ed. Burlington, MA: Jones \& Bartlett Learning.

33. Slimību profilakses un kontroles centrs. 2015. Latvijas iedzīvotāju veselību ietekmējošo paradumu pētījums, 2014. Rīga: Slimību profilakses un kontroles centrs.

34. Slimību profilakses un kontroles centrs. 2016. ESPAD 2015. Atkarību izraisošo vielu lietošanas paradumi un tendences skolēnu vidū. Rīga: Slimību profilakses un kontroles centrs.

35. Stoltenborgh, M., van IJzendoorn, M.H., Euser, E.M., Bakermans-Kranenburg, M.J. 2011. A Global Perspective on Child Sexual Abuse: Meta-Analysis of Prevalence Around the World. Child Maltreatment. 16(2), 79-101.

36. Straus MA. 2010. Prevalence, societal causes, and trends in corporal punishment by parents in world perspective. Law Contemporary Problems. 73, 1-30.

37. United Nations. 2017. Report of the Inter-Agency and Expert Group on Sustainable Development Goal. In: United Nations SDG Indicators. Available from: https://unstats.un.org/sdgs/indicators/indicators-list/ [viewed 17.03.2017.]

38. World Health Organization and International Society for Prevention of Child Abuse and Neglect. 2006. Preventing child maltreatment: a guide to tacking action and generating evidence. Available from: http://apps.who.int/iris/ bitstream/10665/43499/1/9241594365_eng.pdf [viewed 16.11.2016.]

39. World Health Organization. 2013a. European report on preventing child maltreatment. In: World Health Organization Publications. Available from: http://www.euro.who.int/_data/assets/pdf_file/0019/217018/European-Report-onPreventing-Child-Maltreatment.pdf?ua=1 [viewed 17.03.2017.]

40. World Health Organization. 2014a. WHO global plan of action to strengthen the role of the health system within a national multisectoral response to address interpersonal violence, in particular against women and girls, and against children. In: World Health Organization. Available from: http://apps.who.int/gb/ebwha/pdf_files /WHA67/A67_ACONF1Rev1-en.pdf?ua=1 [viewed 17.03.2017.]

41. World Health Organization. 2016. Global health observatory data repository. In: World Health Organization Data. Available from: http://apps.who.int/ gho/data/view.main.CODWORLDV?lang=en. [viewed 01.07.2016.] 


\section{PUBLIKĀCIJAS UN TĒZES PAR DARBA TĒMU}

\section{Publikācijas}

1. Springe, L., Pulmanis T., Velika, B., Pudule, I., Grīnberga, D., Villeruša, A. 2016. Self-reported suicide attempts and exposure to different types of violence and neglect during childhood: Findings from a young adult population survey in Latvia. Scandinavian Journal of Public Health. 44, 411417.

2. Rancāns, E., Pulmanis, T., Spriṇge, L., Velika, B., Pudule, I., Grīnberga, D. 2015. Prevalence and sociodemographic characteristics of self-reported suicidal behaviours in Latvia in 2010: A population-based study. Nordic Journal of Psychiatry. 70(3), 195-201.

3. Spriṇgge, L., Vulāne, K., Pulmanis, T., Villeruša, A. 2015. Latvijas jauniešu psihoemocionālo traucējumu saistība ar bērnībā pieredzētu vardarbību gimenē. Rìgas Stradinga universitātes zinātniskie raksti 2014. Rīga: Rīgas Stradiṇa universitāte.

4. Pulmanis, T., Trapencieris, M., Spriṇge, L., Taube, M. 2015. Pusaudžu pašnāvnieciskā uzvedība Latvijā: pašnāvības plānu sakarība ar ǵimeni, vienaudžiem un skolu saistītiem faktoriem. Rìgas Stradiņa universitātes zinātniskie raksti 2014. Rīga: Rīgas Stradiṇa universitāte..

5. Pulmanis T., Trapencieris, M., Spring̀ge, L., Taube, M. 2014. Pusaudžu pašnāvnieciskā uzvedība Latvijā: sakarības ar atkarību izraisošo vielu lietošanu. Rīgas Stradina universitātes zinātniskie raksti 2013. Rīga: Rīgsas Stradiṇa universitāte.

6. Spriṇǵe, L., Vegnere, M., Pulmanis, T.,Villeruša, A. 2013. Vardarbības rezultātā gūtās traumas skolas vecuma bērniem Latvijā: demogrāfiskais raksturojums, ievainojuma veidi un traumas gūšanas vieta. Rìgas Stradiņa universitātes zinātniskie raksti 2012. Rīga: Rīgas Stradiṇa universitāte.

7. Pulmanis T., Spriṇge, L., Trapencieris, M., Taube, M. 2013. Pašnāvnieciskās uzvedības mūža prevalence un tās izmaiñas dinamikā 15-16 gadus veciem pusaudžiem dzimumu grupās Latvijā. Rīgas Stradiņa universitātes zinātniskie raksti 2012. Rīga: Rīgas Stradiņa universitāte. 


\section{Starptautisko konferenču tēzes}

1. Springe, L., Pulmanis, T., Pudule, I., Grinberga, D., Velika, B.,Villerusa, A. 2014. Association between exposure to physical and emotional neglect in childhood and self-reported lifetime suicide attempts in Latvian youth. Abstract book, 15th European Symposium On Suicide and Suicidal Behaviour. Tallinn, Estonia.

2. Pulmanis, T., Springe, L., Sile, L., Trapencieris, M.,Taube, M. 2014. Association between adolescent self-reported lifetime suicide attempts and use of synthetic cannabinoids and other addictive substances in Latvia. Abstract book, 15th European Symposium On Suicide and Suicidal Behaviour. Tallinn, Estonia.

3. Springe, L., Stars, I., Villerusa, A. 2014. Qualitative studies on violence against children in Latvia. Abstract book, The 4th Regional European Safe Community Conference. Harstad, Norway.

4. Springe, L., Villerusa, A., Pulmanis, T., Pudule, I., Grinberga, D., Velika, B. 2013. Association between exposure to family violence in childhood and selfreported lifetime suicide attempts in Latvian youth. European Journal of Epidemiology. 28, Supplement 1, S213.

5. Springe, L., Villerusa, A., Pudule, I., Velika, B., Grinberga, D. 2013. Childhood family violence exposure and self-rated health in young adulthood in Latvia. Atencion Primaria, 45, 98.

6. Springe, L., Villerusa, A. 2012. Alcohol drinking behaviour of 18-25 aged young adults in association with experienced family violence during childhood in Latvia. European Journal of Public Health. 22, Supplement 2, 223-224.

7. Spriṇgé, L., Villeruša, A., Pudule, I., Velika, B., Grīnberga, D. 2012. Smoking prevalence and its association with experienced violence in childhood: results from young adults survey in Latvia. 5th Annual European Public Health Conference. Portomaso, St. Julian's, Malta. Available from: http://2011.aspher.org/pg/file/read/9700/lauma-sprie-oral-presentation (Viewed: 13.12.2012.) 
8. Spriṇge, L., Villeruša, A. 2012. Addictive substance use behaviour in young adults in Latvia and it association with experienced family violence in childhood. Abstract Book, International conference Youth in Latvia, Europe, Globe: opportunities and risks. Riga, Latvia.

9. Sprinğge, L., Pudule, I., Velika, B., Grīnberga, D., Villeruša, A. 2012. Relationship between experienced childhood violence in family and parental separation or divorce and parental alcohol abuse. Abstract Book, 9th European IUPHE Health Promotion Conference. Tallinn, Estonia. Apbalvots kā labākais stenda referāts.

10. Spriṇgé, L., Villeruša, A., Zīle, I. 2012. Violence-related children injuries in Latvia. Abstract Book, The $12^{\text {th }}$ Conference of the Baltic Association of Paediatric Surgeons. Riga, Latvia.

11. Sprinğge, L., Villeruša, A. 2011. Alcohol and interpersonal violence injuries in Latvia. Abstract Book, 3rd European Conference in Injury Prevention and Safety Promotion. Budapest/Godollo, Hungary.

12. Spriṇǵe, L., Villeruša, A. 2011. Vardarbības rezultātā gūto ievainojumu raksturojums 16-29 gadus veciem jauniešiem. 2011. gada Zinātniskās konferences tēzes. Rīga: Rīgas Stradiņa universitāte.

13. Spriņǵe, L., Rozīte, S., Villeruša, A. 2010. Violent youth injuries in Latvia. Abstract Book, Baltic Public Health Conference 2010 - Accomplishments and Challenges. Tartu, Estonia.

14. Springige, L. 2010. Analysis of adolescent unintentional injury data in Latvia, years 2006-2008. Conference materials, Baltic-Nordic Seminar on Safety Promotion and Injury Prevention among Adolescents and Young Adults. Tallinn, Estonia. 


\section{Latvijas konferenču tēzes}

1. Spriṇgé, L., Stars, I., Villeruša, A. 2014. Ekspertu intervijas kā informācijas ieguves avots vardarbības pret bērniem izpētei Latvijā. 2014. gada Zinātniskās konferences tēzes. Rīga: Rīgas Stradiņa universitāte.

2. Spriṇgé, L., Pudule, I., Velika, B., Grīnberga, D., Villeruša, A. 2013. Bērnībā gimenē pieredzētās vardarbības saistība ar jauniešu veselības pašvērtējumu. 2013. gada Zinātniskās konferences tēzes. Rīga: Rīgas Stradiņa universitāte.

3. Spriṇgé, L., Pudule, I., Velika, B., Grīnberga, D., Villeruša, A. 2012. Bērnībā gimenē pieredzētās fiziskās un emocionālās vardarbības prevalence pēc Latvijas jauniešu pētījuma. 2012. gada Zinātniskās konferences tēzes. Rīga: Rīgas Stradiņa universitāte.

4. Spriṇge, L., Villeruša, A. 2011. Vardarbības rezultātā gūto ievainojumu raksturojums 16-29 gadus veciem jauniešiem. 2011.gada Zinātniskās konferences tēzes. Rīga: Rīgas Stradiṇa universitāte. 


\section{PATEICĪBAS}

Patiesā cieņā un sirsnībā vēlos pateikties darba vadītājai asociētajai profesorei Anitai Villerušai par sniegto zinātnisko un praktisko palīdzību, konsultēšanu un atbalstu promocijas darba izstrādes laikā.

Paužu dziḷāko pateicību par atbalstu zinātniskās publikācijas rediǵēšanā, konsultēšanā un atbalstā promocijas darba izstrādē Toronto Universitātes emeritētai profesorei Ilzei Kalniņš.

Izsaku savu pateicību Slimību profilakses un kontroles centra direktorei Ivetai Gavarei un datu analīzes speciālistēm Ivetai Pudulei, Birutai Velikai un Daigai Grīnbergai par iespēju izmantot pētījuma datu bāzi promocijas darba uzdevumu izpildē.

Pateicību par emocionālo un praktisko atbalstu promocijas darba iztrādes laikā vēlos izteikt arī Sabiedrības veselības un epidemioloǵijas katedras vadītājam profesoram Girtam Brigim un katedras kolēgeèm Andai K̦ìvītei, Ievai Strēlei, Inesei Gobinaai, Anitai Kokarēvičai, Ilonai Torimai, Madarai Dobelei un Lìvai Gobai. Īpašs paldies Inesei Stars par palīdzību un konsultēšanu kvalitatīvās pētniecības jautājumos.

Sirsnīgs paldies manai ǵimenei, īpaši vecākiem Vidvudam un Inesei Springiem, par sniegto atbalstu un rūpēm. 